\title{
Strategic IT alignment Projects. Towards Good Governance
}

\author{
Francisco Maciá Pérez, José Vicente Berna Martinez ", Iren Lorenzo Fonseca \\ Computer Science and Technology Department, University of Alicante
}

\begin{abstract}
A B S T R A C T
The senior management of organisations frequently perceive IT Projects as merely technological in nature. They fail to realise that in reality, the mission of IT is to provide technology-based support to business processes that can be key to the organisation. This lack of understanding means that these IT projects are not aligned with the business objectives and that investments in resources and personnel are not adequately prioritised. This can lead to an opportunity loss: a mere computerising of the business is sought, and processes that could turn out to be transformative, generating added value, driving a true digital transformation of the business are overlooked. This article proposes a model for implementing and operating a portfolio of strategic IT projects. Based on Good Governance principles, these latter projects move strategic decision-making up to an organisation's senior management, succeeding in gradually implicating these managers into the IT strategy. But above all, the model succeeds in achieving the targeted strategic alignment of IT projects with the organisation's business objectives and interests. The model has already been implemented in fourteen medium and large size public universities. The follow-up through interviews of the nine longest-standing experiences—some are nearly a decade old — revealed that the portfolio implementation strategy had helped to markedly improve the following elements: the institutions' state of maturity of Good Governance; senior management's involvement in IT projects; and the identification of the most interesting IT projects for the business. To conclude, based on our experience, we can affirm that the strategic IT alignment projects is an effective IT Governance tool and, by extension, an example of Good Governance practice.
\end{abstract}

\section{Introduction}

Strategic alignment is one of the least tangible and most complex governance mechanisms that organisations must embrace [1]. It ensures, however, that an organisation's IT services are aligned with the business objectives and processes [2]. To achieve this, the process must implicate the organisation's various levels of structures, procedures and activities. Here, communication, cooperation and leadership are essential factors of success; they even come before project management [3].

It is ever more critical to understand that senior management must also govern IT, and that IT governance does not mean the governance or management of IT projects [4]. Unfortunately, in many organisations, governance structures have still not sufficiently evolved and are yet to be convinced that IT projects should not only be managed, but also governed.

The ISO/IEC 38500 standard [5] includes principles and activities for building an IT governance framework. This framework supports different designs and implementations according to the interests, objectives, and structure of each organisation [6]. Whatever the final design, the standard clearly identifies the principles that a management team must follow to achieve good governance: establish responsibilities, make acquisitions, strategy, performance, conformance with rules and respect for human factors [7].
The boundaries between government, governance and IT management are indeed blurred-especially because some standards and management frameworks have been incorporating governance mechanisms $[8,9]$. It is also true, however, that today, most senior managers tend to draw back and widely delegate strategic decisions linked to the development and purchasing of the IT services that support their organisational business processes. It is hard to make senior management understand that this delegating may entail an abandonment of functions that directly breaches the expected application of the Good Governance principle of responsibility $[10,11]$.

This situation causes organisations to simultaneously face two major challenges when seeking to push IT strategic decisions to the uppermost management levels: (a) implicating senior managers to the extent that they become leaders of the strategies and, once achieved, (b) developing a structure, protocols, processes and activities that facilitate their governance and management sustainably over time [12].

Experiences over the last two decades [10] reveal that it is very difficult to tackle the whole scale of the problem, and that experiences with a more limited scope have been much more effective. In our case, we focused on achieving strategic and responsible management of IT projects. An IT project brings together an action or a series of actions, in any business area, with a fixed start and end that effectively responds to one or more of the organisation's strategic objectives, relying heavily on

\footnotetext{
* Coressponding Authors.

E-mail address: jvberna@ua.es (J.V. Berna Martinez).
} 
IT to achieve it. In this sense, the project portfolio is one of the most effective processes to execute the organisation's IT strategy. The reason the impact and visibility that IT projects currently enjoy [11].

Based on this concept of IT project and project portfolio [12], we propose in the present article a strategic project portfolio model as an effective tool to address the problem of IT governance [11]. Worthy of note, the objective is not to delve into the basic governance and management aspects of a classic project portfolio-which, by extension, are assumed to be valid and compatible with the proposal presented here. Rather, we seek to explore the aspects that contribute to making a portfolio strategic, that is, determine which people elaborate the portfolio as well as which criteria rule its content thus leading to decisions regarding the communication flows between the organisation's different levels and structures.

In addition to government and governance processes, another major objective of the strategic project portfolio is to determine how the portfolio's projects should be selected and prioritised; moreover, given the discipline's strategic character, it should be conducted by the organisation's most senior management levels [13]. This requirement, together with the principle of responsibility established by the Good Governance standard mean that the strategic project portfolio is an ideal opportunity to push senior management into getting more actively involved into an organisation's necessary decision-making regarding IT projects.

In accordance with ISO/IEC 38500 [5], its principles and activities, the portfolio governance model proposed here is based on the fact that IT government of the portfolio takes place before, during, and after the governance and management by senior IT managers and the IT Department. Accordingly, the model must: set the conditions for creating the portfolio; determine the criteria for selecting and prioritising projects; consider periodic controls of decision validity based on the project management's execution and its follow-up; and finally evaluate the results based on the value and impact obtained, the effective use and the real costs of the IT projects.

The rest of the paper is structured as follows: first (section 2), the state of the art is reviewed, focusing especially on the evolution of IT management, governance and governance models. Next (section 3), we provide an overview of the proposed model. Before fully developing the model, we analyse its different components, allowing to achieve a specific solution adapted to each organisation (section 4). Thereafter (section 5), we present the model's specifications, expressed through a series of processes. The following section (section 6) describes project governance in more detail as it represents a key element of the solution, together with project prioritisation. All aspects of the model were tested and validated (section 7) in different public universities, creating links between public corporate governance, IT governance, IT management and IT operation and key stakeholders: students, faculty and university administration and service staff. The universities involved managed to reach and strengthen a high level of Good Governance maturity and, as shown in the analysis of this research and the results obtained over almost a decade, the model is easily transferable to a wide range of organisations as a Good Governance practice. The authors of this work have been responsible - in accordance with their respective positions: IT Vice-manager, Scientific Director and Researcher-for designing and implementing the proposed model at the University of Alicante, where it has been operating since 2013. A special analysis is therefore dedicated to this latter case study. To finish (section 8), we expose the main conclusions and future developments.

\section{Background and State of the Art}

It is important to understand that this work does not focus on how a portfolio's projects are managed and operated based on managing standards and norms [14]. The present study addresses how IT projects are governed by top management, following the principles of the ISO / IEC 38500 standard. That is why the main search strings relating to the subject's background centre around keywords linked to "prioritisation, governance and governance of projects", or to "evolution and standards of IT governance."

The latest versions of COBIT [9] already incorporate a reference framework for company IT governance and management. Therefore, we used this good practice guide as a starting point in our present analysis of the state of the art, always remembering, however, that these practices have been primarily designed for those responsible for IT governance and management and not for an organisation's senior management.

COBIT establishes the need for a hierarchical alignment, proposing a governance structure and establishing the levels and relationships among its members. This process has evolved over time [9]. We analyse in the following sections the different models resulting from this evolution. Their ordered series constitutes, in turn, a maturity model that could be very useful to assess at which stage each organisation finds itself in.

One of the earliest models of interest is the one shown in [15], which provides an insight into IT as a service provider that can be easily outsourced or replaced. This model is based on a traditional vision of IT supply and demand and presents a notable lack of strategic alignment.

In [16] an evolution of the previous model is proposed in which IT becomes an asset that creates value for the organisation. The traditional dual domain continues to be maintained but differentiating the strategic, management and operation dimensions in each of them. Although these dimensions represent a big step forward, we must remember that the communication taking place between them is as important as the communication between domains.

To fill the gaps identified in the previous models, a communication flow between the main dimensions is proposed in [15] and [16]. In this flow, a distinction is already made between governance, management and IT operations processes, and a management flow as well as a control flow (which goes in the opposite direction) are established. As a result, the concept of separate business and IT domains starts to disappear, and the domains of decision and the goals and control cascade become clear. Nevertheless, the way these flows should be implemented (a series of good practices) is not defined, for example, how prioritisation should be performed.

Works [13] and [17] present a framework that links corporate governance with IT governance. According to this perspective, IT resources should be governed in the same way as physical assets, human resources, intellectual property, relationships (marketing, commercial, advertising, etc.) and financial resources. In this model, all assets must be governed with the same instruments used to govern assets: defining strategic plans and controlling desirable IT behaviour through measurable progress indicators.

As shown in this review of the different models adopted by organisations to achieve strategic IT alignment, IT resources should be considered as an organisation's physical assets. Moreover, these IT assets are gaining importance and are creating more value for organisations than traditional assets [18].

The reality is that not all organisations have reached the same maturity levels [10]. The later they are in the model, the further away they are also from the structures, processes and principles necessary to achieve Good Governance, and, precisely, the greater the resistance to change. That is why the main IT governance framework, ISO/IEC 38500 does focuses less on improving procedures and more on improving the behaviour of all stakeholders and processes involved [5].

Our study is based on the fact that a strategic portfolio of projects, as opposed to a conventional project portfolio, in addition to providing a framework for IT project governance that is compatible with its structures, governance and management, helps the organisation to achieve the Good Governance principles [11] dictated by the ISO/IEC 38500 standard [5] by elevating strategic decision-making to the most senior management levels.

Our case studies so far have focused on applying this model to IT governance in the public sector, more specifically to a dozen medium 
and large public universities. In this regard, literature exists on the subject, confirming the general interest in providing solutions for this sector. Some proposals are more generic such as [19] and [20], others are more focused on public government and governance [21] and others still focus more on IT governance and IT management aspects regarding risks and IT security [22].

The model proposed in this research is consistent with the best practice guides proposed by the main reference frameworks such as ITIL or COBIT. These frameworks are not designed to set up projects related to the implantation of the framework itself, but rather to guide organisations on how to identify internal deficiencies, define which deficiencies should be given priority and how to implement improvements. They leave the setting up as a separate task that each organisation must address based on its own characteristics [23,24]. For example, COBIT proposes governance and management structures, ITIL outlines governance in its ITIL Service Strategy, ITIL again delves deeper into management processes in its Service Design, Transition and Operation lifecycle using structures based on layers. Both frameworks may guide you through Continual Improvement. COBIT provides an Integral Dashboard aligned with business objectives and a guide on Evaluating Results.

From a methodological viewpoint, to avoid ambiguous definitions as much as possible and to seek a framework that is as formal as possible $[25,26]$, we chose to base the proposal on the Business Process Model (BPM), described using the Universal Modelling Language (UML), more specifically using the Eriksson-Penker notation [27] for the BPMN notation[28].

The analysis of existing literature and maturity models on IT governance and project management revealed the need to advance in certain aspects of IT government and governance. It also pointed, however, to the importance of respecting existing structures and management processes and always facilitating their evolution; indeed, many are based on frameworks and standards such as COBIT [9], ITIL [29] or ISO / IEC 20000 [30]. The proposed solutions should focus to a much greater extent on improving the behaviour of the actors and process involved, respecting the principles and activities of Good Governance proposed by the ISO/IEC 38500 standard [5].

\section{IT Strategic Portfolio Model. Overview}

Before contemplating a solution, we must first consider the potentially huge inertia affecting the organisations in which the model will be implemented. This inertia not only accentuates typical resistance to change, but in many cases, it makes change itself impossible, due to inherited structures and an insufficient state of maturity that would allow to assimilate Good Governance concepts. For this reason, we must look for a model that focuses on the evolution and growth of people, rather than on replacing or re-engineering processes. Thus, the proposed solution seeks to maintain the structures and processes that are already implemented as much as possible, proposing changes when necessary and, above all, creating new processes and structures around the existing ones that complement them.

The main objective of the strategic IT project portfolio is not to improve project management, or even to improve a possible portfolio of IT projects. Its objective is to align this management with the organisation's strategy, elevating decision-making to the most senior management levels. That is why, as shown in the diagram presented in Fig. 1, the proposed Model (the ITPP Strategic Model or SITPP) incorporates into the traditional project portfolio model (Conventional ITPP Model), the government (Strategic IT alignment Projects) and governance (Governance of IT Projects) processes into the existing management processes (IT Project Management). It also centres on connecting them all and proposing the necessary artefacts (University Strategy, Prioritised IT Project List) to achieve the desired alignment with the business strategy. The model is conceived in such a way that it largely respects the organisation's established processes while it also facilitates the incorporating of new processes drawn from reference frameworks such as COBIT and ITIL or, naturally, the modifications of existing ones.

More specifically, the IT Projects Strategic Alignment process aims to draw up a prioritised list of IT projects that the organisation is interested in developing. A large group of actors participates in the prioritising, but this prioritisation is led by the organisation's most senior governance bodies. The enterprise's organisational aspects and resources are considered, though the bulk of the decisions is based on corporate strategy. We will go into more detail later about this prioritisation.

Thanks to this new governance process, the software development process no longer feeds merely off a more or less arbitrary list of IT project requests but the strategically prioritised list of IT project requests. This is key to achieving the desired objective without having to intervene in the current IT Project Management process. A new activity is simply added if it does not exist already: the project's pre-analysis. This activity runs, in an agile way, a first technical assessment of the project. In this way, the governing team will dispose of more accurate information on a project's required deadlines, technical feasibility, costs, structures and its material and human resources. The strategic criteria helping to obtain the prioritised list are also applied in this activity; benefits, risks, key dates, needs, alignment with the strategic plan are analysed, feasibility is studied and the development or implementation costs (in terms of time, people and other factors) are estimated. This

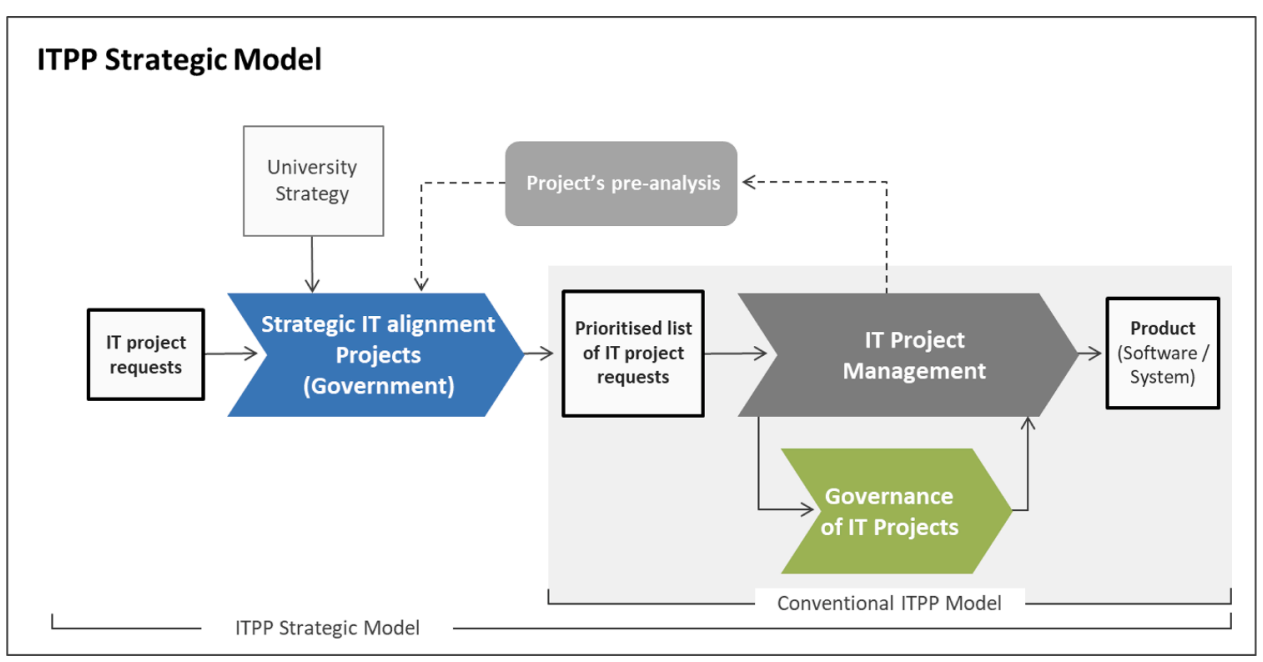

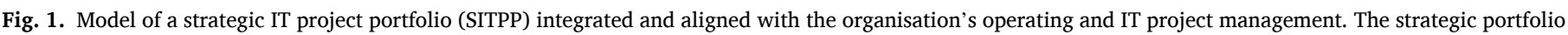
of projects is related to the traditional project portfolio, as well as IT government, governance, and management activities. 
information will be crucial for managers to prioritise the projects in a strategic, but also realistic way.

The second major process that is part of the proposed solution is the IT Project Governance Process. This process plays a key role in regulating how the organisation's Governing team or senior management will interact with the process of managing IT projects. This process consists of a systematic communication mechanism between all value chain actors and processes involved in the IT project. The activities defined here will determine who will intervene in a process phase, how they will do so, and how they will relate to the rest of the actors. In addition, the process will be based on the business rules proper to each organisation. These rules could be dynamic or, in the most stringent cases, totally static. Basing the process on business rules will greatly facilitate the adaptation of this simple yet critical process to each organisation.

The IT Project Governance process will also have to solve problems arising from project monitoring needs, ensuring that contingency plans or schedule deviations continue to be aligned with the strategy. It will have to determine how potential regulatory or political changes, both internal and external, affect a project, justify the state of development, as well as determine which actors can make decisions at each stage and what their scope may be. Therefore, it is necessary to consider how required projects regarding different issues (of a normative, political, strategic nature, etc.) outside the call are incorporated. In summary, the Governance process will be responsible for maintaining the portfolio's strategic alignment once it is launched.

The methodology allowing to adapt the proposed model to each organisation is composed of two major stages. The organisational level can naturally be an institution as a whole, but it can also consist of an independent unit such as a faculty or organisational unit, provided its degree of autonomy is sufficient to conduct its own IT governance. The first stage (Section 4), in turn, is divided into three major steps: identifying the major phases of each call for proposals in the strategic IT project portfolio (section 4.1); identifying the agents involved as well as the essential roles and structures required for a good performance (section 4.2); and identifying a project's possible different states at any time (section 4.3). Based on the study carried out in the first stage, the solution is expressed during the second stage (section 5 ) in the form of a series of processes, sub-processes and activities, paying special attention to the governance process that is addressed in more detail in Section 6 .

\section{Stage 1. Identification of Main Components}

\subsection{SITPP phases}

The first portfolio phase is the setup phase. This phase will only occur once and, although it is obviously essential to its successful establishment, it will also have a big impact on its future viability. Despite its importance, this phase is beyond the scope (and length) of this article, although an extensive explanation can be found in [11] together with examples of successful experiences.

Once the project portfolio is set up, its implementation will be structured through successive calls. The most common practice is to establish an annual call. However, each organisation is free to set its own periodicity. It can be as valid to have two or more calls within a year than to have biannual or triannual calls. The yearly basis is closely linked to making it coincide with the organisation's accounting year to better fit all the portfolio processes into the rest of the organisation's management processes. Experience will help determine the optimal timing in each case.

Whatever the final periodicity, each project portfolio call will be part of one of five phases: Phase PH1 or Preparation Phase, Phase PH2 or Study Phase, Phase PH3 or Planning Phase, Phase PH4 or Execution Phase, and Phase PH5 or Completion Phase. These phases are sequential, so we will always start with phase PH1 and end with the PH5 phase. Below we take a closer look at each proposed phase.
- Preparation Phase (PH1). In this phase, each new edition of the project portfolio is planned and culminates with the publication of the call to participate in the project portfolio of that edition. During this period, the calendar must be prepared, the regulations must be updated, the prioritisation criteria must be set, the budget must be fixed, and the President's letter must be drafted: as the head of the organisation, the President will initiate the new call. In the second year of the portfolio's implementation, a report on the state of the current year's project portfolio must be included in this phase to know which projects have to be requested again or automatically extended, and the criteria to apply in each case.

Although this phase is very short in terms of duration, it is nonetheless critical regarding the rest of the process insofar as it will lay the foundations that will guide the entire call. To fulfil the intended Good Governance principles, all the documentation generated in this phase and all the decisions taken will be made public with the call's publication.

- Study Phase (PH2). The study phase begins once the call has been published. IT project requests are collected, their technical and strategic feasibility are reviewed, and their necessary funding and resources are assigned. This phase ends with a preliminary proposal that is prioritised, applying executive criteria and restrictions that were established and approved during the preparation phase.

This phase covers most of the IT Projects Strategic Alignment Process proposed in the general solution in Fig. 1 but does not end with the final prioritised list of projects. It is limited to achieving a first proposal of a more executive nature. This list will become strategic in the next phase.

- Planning Phase (PH3). Given the complexity of most IT projects, the purely executive application of regulations does not ensure outcomes in line with the interests of the organisation's senior management. For this reason, in order to comply with the principle of responsibility, it is the organisation's Governing board (or the equivalent collegiate body) that will finally agree on a prioritised list of IT projects, determining the planning and above all a timeline to execute each IT project throughout the current call. In doing so, the Governing board will always consider the preliminary prioritisation proposal obtained in phase $\mathrm{PH} 2$ and all the regulations approved in phase PH1, acting in accordance with the criteria and knowledge of the organisation's interests and strategy. Moreover, it is these senior managers who must also indicate which projects are clearly viable, which projects can hardly be carried out given current resources and interests, and which projects are unlikely to be carried out.

The duration of phase PH3 is very short and could well be considered as a sub-phase included in the $\mathrm{PH} 2$. PH3 is, however, highly strategic, and it is important to clearly understand this stage as pivotal amid the preparation and alignment processes and the beginning of the execution of IT projects.

- Execution Phase (PH4). Like phase PH2, phase PH4 covers most of the second proposed solution (see Fig. 1). This phase will be temporarily and functionally related to the IT Project Management Process and, more still, to the IT Project Governance Process. The IT Project Management Process now disposes of an entry point with the list of IT projects prioritised by the Governing team. Nevertheless, this latter list, the strategic conditions and regulations may all vary as the project portfolio call unfolds. In addition to responding technically and organisationally to these changes, the senior management must be made aware and take relevant decisions. The processes suggested in this phase aim at following up project governance by regulating the Governing Team's intervention via the IT project management 
process and by ensuring that strategic and political decisions remain aligned with technical, technological and organisational decisions.

- Completion Phase (PH5). In the completion phase, it is necessary to ensure that all IT portfolio projects reach some form of completion. This completion does not have to be definitive. A project may even be extended. In this phase, each project will be individually assessed, and the project portfolio's overall implementation will also be evaluated. The evaluation of the portfolio itself must be carried out at a sufficiently distant date to appreciate the project's benefits. It can be based on surveys conducted with requesters and promoters as well as on result analyses. All the information generated at this completion stage will be crucial both for purposes of transparency and to assist the Governing team in their decision-making.

\subsection{Roles and Structures}

The next step in building a solution based on this model is to identify and classify all the roles involved in the process. To do this, we first list the different agents having participated in the different experiences in which work has been accomplished. Since these experiences have so far focused on public universities, the specific names of the positions are proper to these institutions. Of interest here, however, is what their attributions consist of, and the latter must be easily extrapolated to any other type of organisation. The classification described below was established based on these actors and the sum of the tasks they performed. We must remember that at this point, the objective is to identify the roles, not the people or the positions.

Different agents take part in preparing the IT Project Portfolio. They are described below. Table 1 schematically illustrates the range of roles identified.

- Requester: The person who requests the project, justifies its necessity and its benefits, elaborates the project's report and defines its milestones. It is recommended that the Requester know perfectly the domain of implementation of the IT project, so the person must be a coordinator, or head of unit or service, although not necessarily be functionally dependent on the Promoter.

- Promoter. This is the person who proposes the project and is tasked with defending the need for it or reasons to implement it before the Governing Team. It must necessarily be a Vice-Chancellor (in the case of universities, each Vice-Chancellor is the top person responsible for a given management domain, similar to a general manager), the Manager or some other member of the Governing Team, as he or she must have the biggest decision-making capacity.

- Project Manager (PM). This person is assigned by the Project Promoter to subsequently manage and execute the project. He or she will be responsible for fulfilling the proposed objectives. It is recommended that the project manager be perfectly knowledgeable of the domain in which the IT project will be implemented. This person must therefore be a coordinator, or a head of unit or service, but does not necessarily have to be functionally dependent on the Promoter.

- IT Project Portfolio Office (PPO). This person will be responsible, among many other tasks, to: advise Portfolio users in the course of its different phases, especially when drafting a proposal for an IT Project in strategic terms; to inform the Vice-Chancellor on which IT Project proposals are properly developed and gather sufficient information to be considered as candidates; to elaborate the evaluation report of the IT Project proposals and transmit them to the Vice-Chancellor of IT projects; and to prepare reports to monitor the execution of IT Projects and to report them back to the Vice-Chancellor of IT Projects. Given the role played in this model by the PPO, more details will be given later.

- Governing board (GB). Initially, the Governing Team (whether the Governing board or otherwise) will be responsible for establishing the funding allocated to the Project Portfolio over the following year, as well as the criteria to follow when establishing the priorities. Once
Table 1

Roles identified in the strategic IT project portfolio.

\begin{tabular}{|c|c|c|c|}
\hline Abbrev. & Agent & Composition & Summary of functions \\
\hline Requester & Requester & $\begin{array}{l}\text { Director of } \\
\text { administration, service, } \\
\text { unit, centre, etc. }\end{array}$ & $\begin{array}{l}\text { Prepares the project's } \\
\text { report (in most cases, } \\
\text { the same figure as the } \\
\text { Project Manager). } \\
\text { Note: Departments can } \\
\text { submit their } \\
\text { applications through } \\
\text { their centre. }\end{array}$ \\
\hline Promoter & Promoter & $\begin{array}{l}\text { Members of the } \\
\text { Governing board }\end{array}$ & $\begin{array}{l}\text { Proposes and defends } \\
\text { the projects of their } \\
\text { domain before the GB. } \\
\text { Must reject projects that } \\
\text { are little strategic so as } \\
\text { not to create false } \\
\text { expectations } \\
\text { Allocate funding and } \\
\text { resources (if necessary). } \\
\text { Designate the Project } \\
\text { Manager }\end{array}$ \\
\hline PM & $\begin{array}{l}\text { Project } \\
\text { Manager }\end{array}$ & $\begin{array}{l}\text { Director of } \\
\text { administration, service, } \\
\text { unit, centre (or whoever } \\
\text { delegates), etc. }\end{array}$ & $\begin{array}{l}\text { Monitors compliance } \\
\text { with project execution } \\
\text { times and objectives. } \\
\text { In the event of incidents } \\
\text { or unforeseen events, } \\
\text { coordinates any } \\
\text { additional necessary } \\
\text { actions to achieve } \\
\text { proper compliance. } \\
\text { It may temporarily } \\
\text { suspend a project on the } \\
\text { basis of operational } \\
\text { aspects and always in } \\
\text { accordance with the } \\
\text { Promoter. }\end{array}$ \\
\hline PPO & $\begin{array}{l}\text { Project } \\
\text { Portfolio } \\
\text { Office }\end{array}$ & $\begin{array}{l}\text { IT Vice-manager (or } \\
\text { equivalent) (and his or } \\
\text { her team) }\end{array}$ & $\begin{array}{l}\text { Coordinates and } \\
\text { manages the project } \\
\text { portfolio. }\end{array}$ \\
\hline GB & $\begin{array}{l}\text { Governing } \\
\text { board }\end{array}$ & $\begin{array}{l}\text { Chairman and members } \\
\text { of the management team }\end{array}$ & $\begin{array}{l}\text { Define the strategic } \\
\text { pillars and prioritise the } \\
\text { portfolio of projects } \\
\text { according to these } \\
\text { pillars. }\end{array}$ \\
\hline CIO & $\begin{array}{l}\text { Top IT } \\
\text { Manager }\end{array}$ & $\begin{array}{l}\text { Top Strategic Head of IT } \\
\text { and his or her Board of } \\
\text { Governors Directors }\end{array}$ & $\begin{array}{l}\text { Coordinates the } \\
\text { alignment of the project } \\
\text { portfolio with the } \\
\text { university's strategy and } \\
\text { is the link between the } \\
\text { GB and the PPO. } \\
\text { Oversees the operation } \\
\text { of the project portfolio } \\
\text { and reaches agreements } \\
\text { with the Promoter in } \\
\text { case of unforeseen } \\
\text { events, acceptance of } \\
\text { new projects or priority } \\
\text { changes. } \\
\text { May temporarily } \\
\text { suspend a project for } \\
\text { strategic reasons in } \\
\text { agreement with the } \\
\text { Promoter. }\end{array}$ \\
\hline ITS & IT Service & $\begin{array}{l}\text { Director of the ITS and } \\
\text { its staff }\end{array}$ & $\begin{array}{l}\text { Technical management } \\
\text { of the project. } \\
\text { May stop a project due } \\
\text { to a lack of resources, or } \\
\text { relaunch a suspended } \\
\text { project when available } \\
\text { again }\end{array}$ \\
\hline Other & $\begin{array}{l}\text { Other units } \\
\text { or services }\end{array}$ & $\ldots$ & $\begin{array}{l}\text { Provide services or } \\
\text { perform additional tasks } \\
\text { to correctly execute the } \\
\text { project }\end{array}$ \\
\hline
\end{tabular}


the proposals have been received, it will analyse the requests, determine their priority based on the established criteria, draw up the final project portfolio, which helps to define the following year's IT budget and inform the rest of the university community.

- Chief Information Officer (CIO). This person is responsible, among other tasks, for promoting the implementation and proper exploitation of the IT Project Portfolio; overseeing the running of the IT Project Portfolio Office; advising promoters and helping to coordinate IT-transversal projects involving several vice-chancellors or services; of giving the go-ahead to the IT Projects list and the evaluation proposal and transmitting it to the Governance Team so that it be given priority; finally, the CIO is responsible for tracking the execution of the IT projects included in the portfolio and informing the Governing team of their successful outcome.

- Technical Support (ITS). The IT Service will designate one or more persons who could give (technical) advice to the Promoter and the Project Manager during the proposal's elaboration.

Plainly, this list of actors may vary a little, or widely, according to each organisation. It is also clear that other actors are involved and that they will at some point perform additional tasks to correctly execute the different projects. However, the range of tasks, whether performed by one actor or another, must be fairly uniform, regardless even of the organisation in question. To achieve this uniformity and a more generalised proposal, the identified tasks are described as a series of roles. This means the responsibilities and activities related to a project portfolio can be treated independently from the persons or organisational structures that will bear those responsibilities or who must perform determined tasks.

In our experience, the Project Portfolio Office (PPO) plays a major role in the success of the strategic project portfolio, acting as a catalyst. For this reason, in addition to playing an essential role in the proposed model, it is also recommended to create a specifically dedicated structure. At the very minimum, this structure should be made up of a physical office and a Director of that office. The role, the physical office or the Director or group of workers who perform the role are referred to indistinctly in the rest of the document using the acronym PPO. Table 2 shows the main tasks to be performed by the PPO.

Although we avoid approaching here the issue of portfolio management, there is a management side that includes strategic components such as the tasks above.

We could also discuss the structure of the PPO for use cases. The PPO may consist of a single a person, as in our case, or of several people.

\subsection{States of an IT project}

In this section we identify all the possible states of each portfolio IT project, and we build a general states diagram and their transitions.

By starting with the definition of a states diagram, we obtain a simple yet excellent tool to build the desired solution. On the one hand, identifying the states is fairly independent from the agents, roles, resources,

Table 2

Main tasks performed by the Project Portfolio Office (PPO).

\begin{tabular}{l} 
Summary of functions \\
\hline Assess each project's risk. \\
Identify multiannual projects and attempt to get the requester to break them down. \\
Study which projects can be outsourced. \\
Decide which projects are launched at any given time, which running projects should \\
be stopped and vice versa. \\
Define the strategic pillars and prioritise the portfolio of projects according to these \\
pillars. \\
Manage conflicts, keeping the CIO informed. \\
Request for projects outside the call, inform the CIO. \\
Assess project completion. \\
Identify similar or related projects and facilitate synergies between them. \\
Identify and resolve dependencies between projects.
\end{tabular}

schedules and, above all, the processes involved in the project portfolio. On the other, once the states and the associated transition diagram have been identified, we will dispose of very precise information allowing us to infer the optimal range of processes that will ensure the transition from one state to another until reaching a state of completion.

In this way, the story that we are building not only ends with the portfolio model that we are looking for, but it also explains the method used to reach this solution. Given the great disparity of cases found in each organisation, disposing of the method ensures that our proposed portfolio model is general and will even apply to situations that were unforeseen in this work.

The states diagram starts from the second phase (PH2) because the first phase (PH1) is one of preparation, especially documentation and planning and there are no projects yet. A general diagram is presented later, in Fig. 6, showing all the identified states. But before reaching this diagram, we will gradually build it up, following the different phases of the entire process.

As explained above and as can be seen in Fig. 2, we begin with phase $\mathrm{PH} 2$ or the study phase. We start with the Requester's project request, so that a project's first state (S01) corresponds to a recently presented project; it is pending the project portfolio office's evaluation regarding its basic viability and conformity with regulation requirements.

Once validated, the project moves to a second state (S02) where it remains pending the approval of a developer. The promoter must be the top political person in charge (just below the President) with competences in the domain of the expected solution, service or support. In our case, these responsibilities fall, as we saw in the previous sections, on the Board of Governors. If the developer approves the project, he or she will have to assign both the necessary financing and a project manager.

This milestone brings the process to the next state (S03) in which the project will be pending the ranking proposal by the Vice-Chancellor with IT competencies (or the most senior political person in charge of information technology at the university), who will prepare a preliminary ranking proposal.

This latter action takes the project to a new state (S04) in which it will be pending ranking by the Government Team, made up of the promoters and the Chancellor him or herself. We must remember that all the states analysed so far have always evolved during the $\mathrm{PH} 2$ phase or the project presentation and study phase.

With the final ranking carried out by the Governing Team, each project will move to one of the following states: S05 (ranked and accepted), S06 (ranked and pending availability) and S07 (ranked and unscheduled). All these states occur within the PH3 phase or planning phase.

The ideal situation would be that all projects would be in an $\mathrm{S} 05$ state (ranked and accepted), but the reality is that the number of projects requested will be above the developing capacity, due to lack of staff, time, budget or any other type of resource. Therefore, we need the option of also prioritising non-accepted projects, but without any guarantee that they will be implemented (S06 - ranked and pending availability). It is possible that, as the project portfolio call unfolds these projects may be addressed due to a variety of factors. However, there may also be so many projects to prioritise that we clearly know in advance that it is unlikely they be carried out, or at least with great difficulty. To prevent false expectations, the third ranking (S07- ranked and unplanned) is proposed. While it may seem a better solution to remove such projects from the portfolio, for political reasons and for the sake of transparency, it is not apparently justified. That is, if the project meets all the conditions published in the call, following what criterion should it be removed? Although it may generate controversy, in the medium and long term this exercise of transparency, accountability and performance will eventually build trust and may even reveal that it would be highly strategic to invest more resources or financing in IT.

Although from a formal point of view, it could be understood that the PH2 and PH3 phases are similar in nature, given the relevance of obtaining a published list of prioritised projects for the next project 


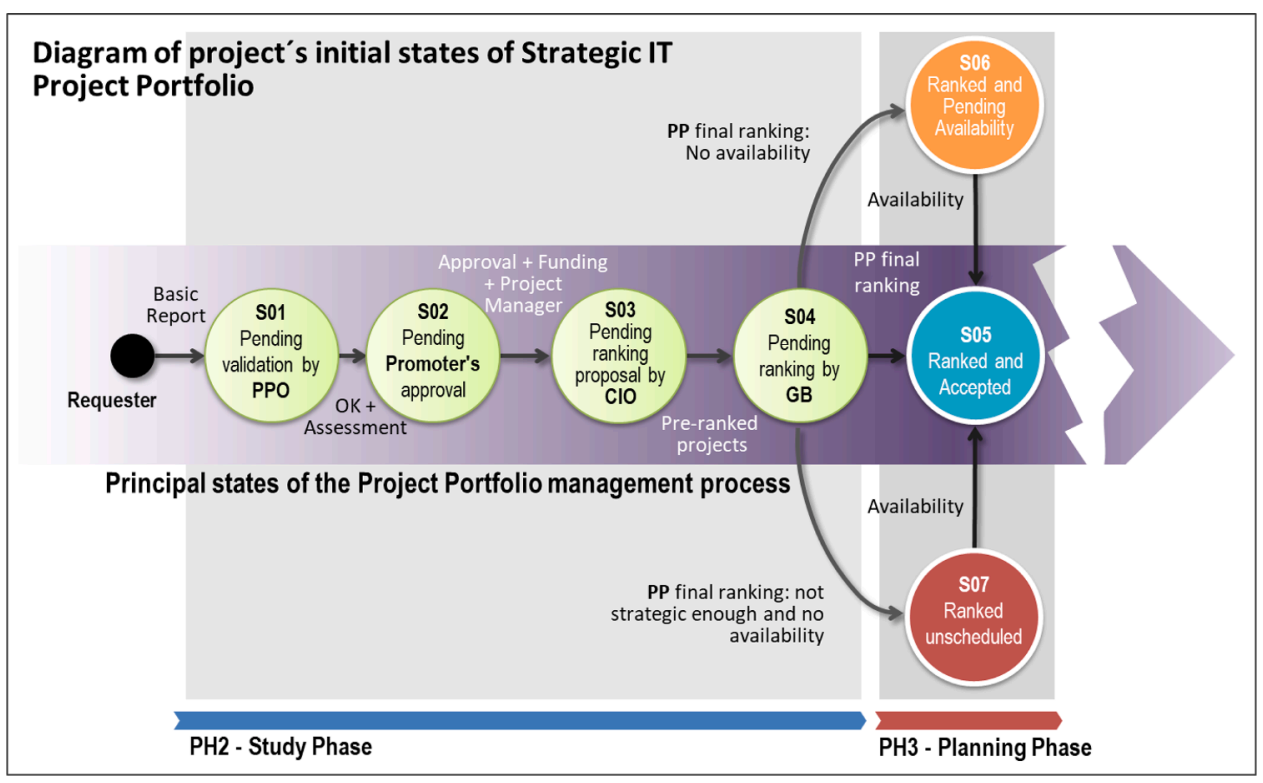

Fig. 2. A diagram of the possible initial states of each IT project included in the strategic IT project portfolio.

portfolio call, we wished precisely to emphasize it by applying this small distinction. This prioritised list is essential to achieve the necessary decoupling between Project Portfolio processes and IT Project Management processes, ensuring that the IT Service (or the staff of the Services and Units involved in the project generally) will enjoy sufficient autonomy to manage their service as they deem best in each case.

On the other hand, the general philosophy of the Project Portfolio is, and should always be, to maintain as fixed as possible both the prioritisation of projects decided and published, and the projects that had been accepted and incorporated according to the conventional terms established by the regulations. Despite this, the option of exceptionally making changes in these regulations should be left open. These changes can only be proposed and approved by the Government Team and will affect projects exclusively in states S05, S06 and S07 of this phase. The latter will almost certainly provoke a cascading effect, though always affecting these three states. For example, if a project initially ranked in state S06 (pending) can or must be launched, it will almost certainly affect at least some of the projects planned in S05, which will probably have to move, now, to S06.

During its study phase (states S01, S02, and S04), a process could move to an FSB completion state because it is rejected. This rejection can be due to a variety of factors and involve different actors (Fig. 3).

According to the above (see Fig. 3), a recently requested project (S01) that does not comply with the regulations or that presents some type of deficiency, may be directly rejected by the Project Portfolio Office (PPO). Likewise, once the project is approved (state S02), the Promoter may reject it if he or she considers that it is not strategic enough or its alignment with the University's strategy has not been sufficiently justified. Finally, during the process of prioritising all projects (state S04), the Government Team itself may decide to reject a project if it considers that it is not strategic enough. In all cases, the projects will pass to the final FSB state.

The dynamics radically change from the moment the final prioritised list of IT projects for the current call is published (Fig. 4). From then on,

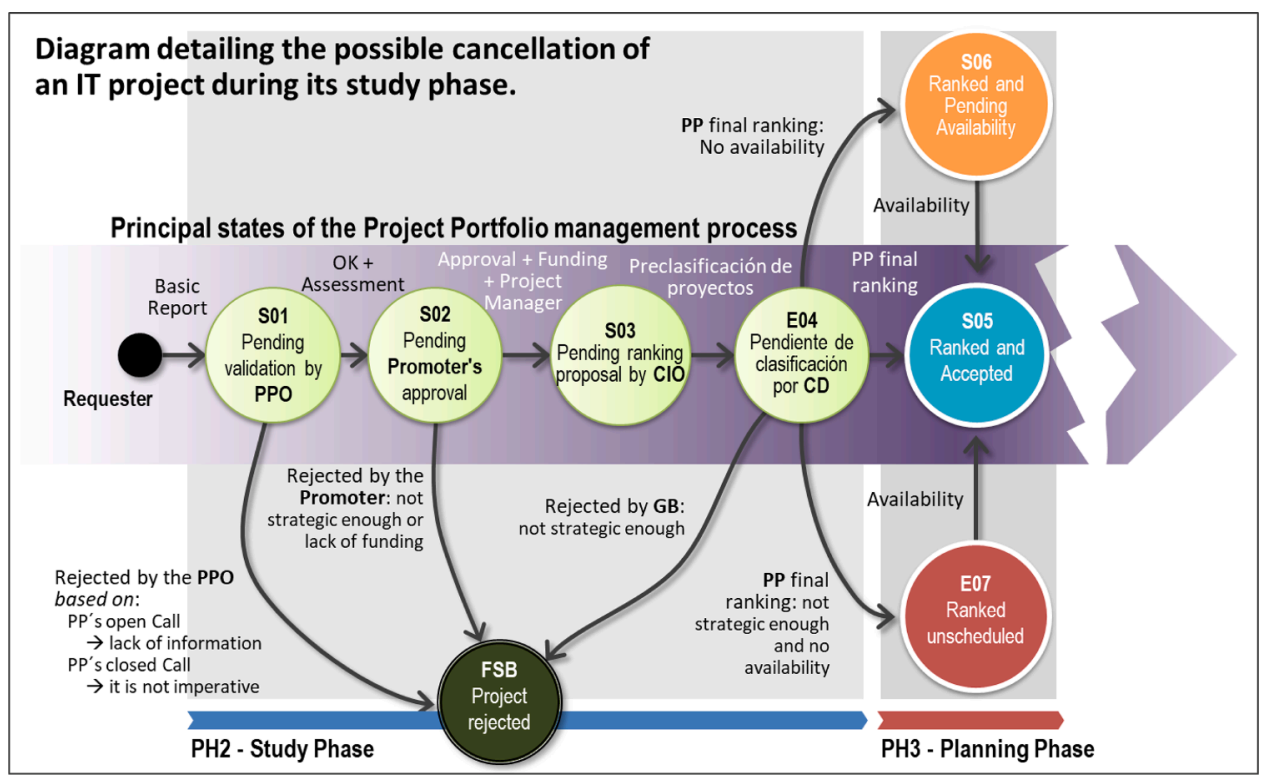

Fig. 3. States diagram detailing the possible cancellation of an IT project included within the IT project portfolio during its study phase. 


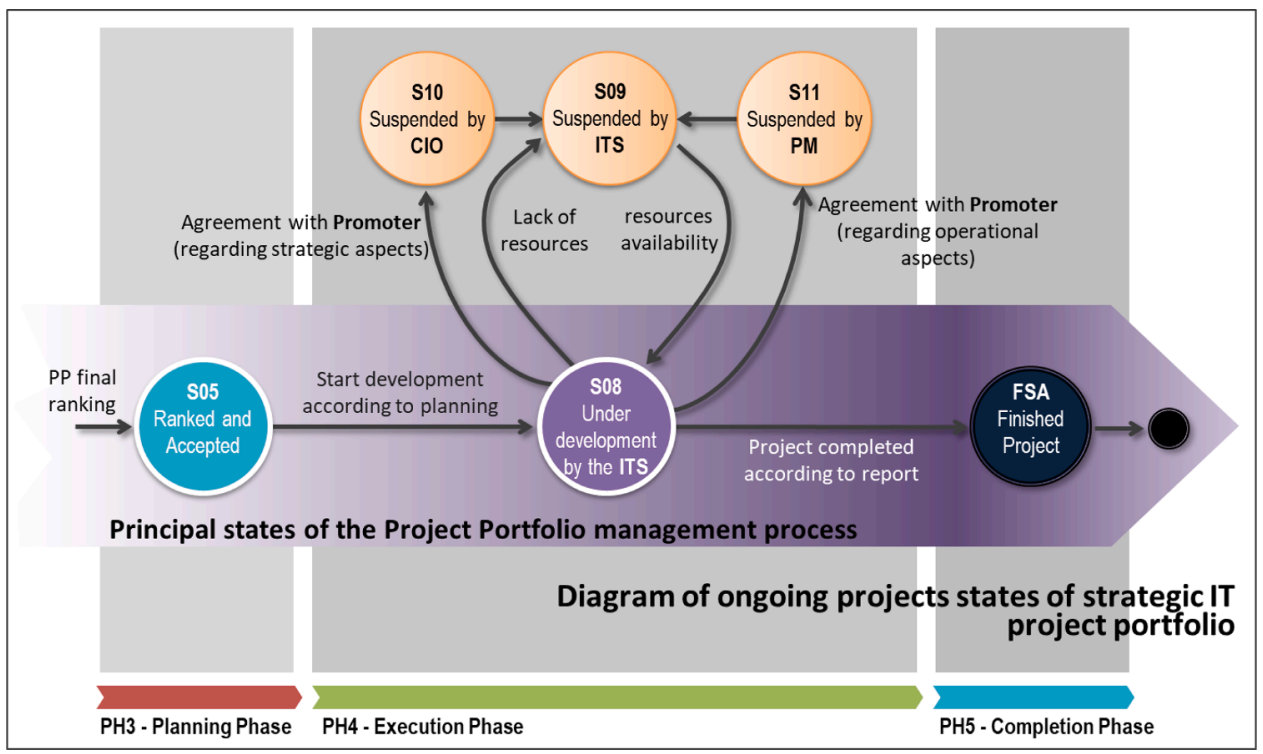

Fig. 4. A diagram of the possible initial states of each IT project included in the strategic IT project portfolio during the execution phase.

it will be the project development unit, team, or service (for example, the IT Service) that will be responsible for executing the projects, according to the order and timetable published during the previous phases. They will now be generally responsible for the project's evolution throughout the value chain until its completion. Accordingly, the portfolio will enter phase PH4 or Execution Phase, and each launched project will pass on to state S08 (under development by the ITS).

During its execution (state S08), a project may be temporarily suspended one or several times. This is when it is important to regulate the scope of the IT Service's decision-making, the nature of the relationship with the Government Team and the Government Team's intervention. The overall objective is to solve possible incidents and get the project back into S08 state as quickly as possible.

The suspension states, in principle temporary, are as follow: S10 state of suspension by the Vice-chancellor with IT powers, always in agreement with the Promoter and always regarding strategic aspects; S09 state of suspension by the IT Service due to technical problems, generally due to an unexpected lack of resources; and S11 state of suspension by the Project Manager in agreement with the Promoter and due to operational aspects.

When a project (in state S08) ends, it will go to the FSA state or finalised state (see Fig. 5). Once this state of completion is reached, the chain of value-generating processes will have been developed satisfactorily. However, in addition to the states of suspension, which will derive from this value chain, some situations also arise that cause states which are less desirable in this case of finalisation, but that are equally essential. Accordingly, all projects in phase 4 of execution but not in S08 at the end of the current project portfolio call will also have to move to a state of completion. In this case, that state would be the FSC state of definitive suspension of the project by the management team.

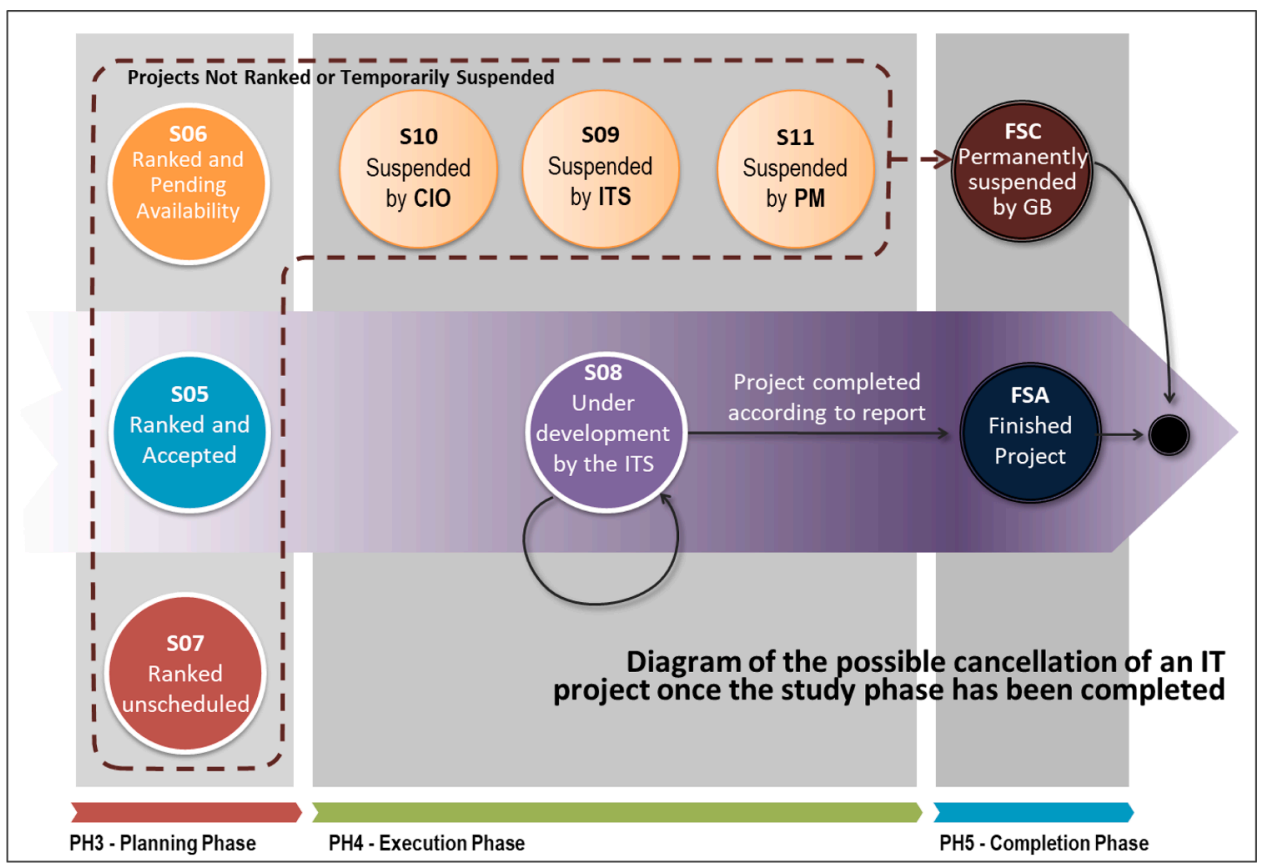

Fig. 5. States diagram detailing the final completion or possible cancellation of an IT project included in the strategic IT project portfolio once that project has already been definitively planned. 
This implicit guide of good practices recommends opting for this solution for these types of projects. In practice, however, many situations will arise that will make us think of changing criteria and, under certain conditions, deciding that certain projects be prolonged in the very state they are in, only in the next call. We must insist that, although this may be an acceptable solution, it should be included in advance in the approved regulations. We should also be aware that this prevents the project from competing with the rest of the projects (new or old) and its strategic value must be updated, which will surely change from one call to another.

Finally, Fig. 5 shows a last case in which feedback occurs in state S8. This feedback corresponds to the possibility that a project, that is under development and that does not present any relevant incident preventing it from being normally completed and relatively soon, may be automatically extended over the next call for proposals at the end of the project portfolio execution period. According to the above, this project will go directly to state $\mathrm{S} 08$ in the new call. This means that a project that has unfolded without problems, but that has run a little short of time to complete itself, may continue to run over the next call.

Table 3 summarises all the states that have been identified. Each state is listed with its manager and the portfolio phase it is part of.

Fig. 6 shows a diagram offering a global view of all the states that have been identified, along with their corresponding steps.

\section{Stage 2. Defining the Model Processes}

Once we dispose of the main elements to build the proposed solution (phases, agents, roles, states), we may go on to define the main processes on which it will be based and which, as can be seen in Fig. 7, derive almost directly from the project's states. Once again, we must remember that, if the states analysis produces a different result from the one proposed here, the solution's essential processes can be extracted almost automatically by simply applying this same method.

Thus, taking into account all these identified factors, we will define a series of transformative processes (P1 to P5) for the PH2 and PH3 study and planning phases tasked with moving each project from its application state to its planning state (states S05, S06 and S07). As mentioned already in the section above, phases $\mathrm{PH} 2$ and $\mathrm{PH} 3$ can be described as a single phase; however, given the importance of project prioritisation by the governance team presented throughout the process, we also highlight here the P5 process which is precisely dedicated to creating and publishing the decision. P5 is the process that contributes the most to the institution's application of the Good Governance principles of transparency and accountability. Thus, the P1 to P4 processes are more closely linked to participation and, to a lesser extent, to transparency and accountability.

As can be seen in Fig. 7, a P6 process has been incorporated into the proposed solution in order to maintain the possibility of making one-off changes to the final prioritisation list once we have moved on to the PH4 implementation phase. These changes must be exceptional (for example, due to a change in legislation, due to legal imperative, etc.) and should be well reflected in the project portfolio regulations. Indeed, although it is almost essential to contemplate this possibility in practice, the very fact it exists may cause mistrust among the community.

For the execution phase $\mathrm{PH} 4$, a single, large process was defined (P7). This process is not transformative in nature, unlike those analysed so far. It is a management process that models the interactions between the management team, the software development service and the rest of the services and units involved in the project, in order to ensure the follow-up of project development Governance. Because these interactions are complex, we will delve a little deeper into this P7 process in section E), dedicated to Portfolio Governance.

Finally, processes P8 and P9, in the phase 5 of completion, will address two important tasks: finalising the projects and reporting the results of the call. It is precisely this latter activity that leads the solution to contribute to another fundamental principle of Good Governance:
Table 3

States of a project in the project portfolio.

\begin{tabular}{|c|c|c|c|c|}
\hline Phase & Cod. & Name & Man. & Description \\
\hline \multirow[t]{4}{*}{ Study Phase } & $\begin{array}{l}\text { S01 } \\
\text { (S01) }\end{array}$ & $\begin{array}{l}\text { Pending } \\
\text { validation by } \\
\text { PPO }\end{array}$ & PPO & $\begin{array}{l}\text { The PPO will validate } \\
\text { and assess the project } \\
\text { according to the } \\
\text { established evaluation } \\
\text { criteria (S02). } \\
\text { It will identify whether } \\
\text { the project can be } \\
\text { outsourced and } \\
\text { whether it needs } \\
\text { additional funding. } \\
\text { May reject the project } \\
\text { due to lack of } \\
\text { information to carry } \\
\text { out the evaluation } \\
\text { (FSA). }\end{array}$ \\
\hline & $\begin{array}{l}\text { S02 } \\
\text { (S02) }\end{array}$ & $\begin{array}{l}\text { Pending } \\
\text { Promoter's } \\
\text { approval }\end{array}$ & Promoter & $\begin{array}{l}\text { The Promoter will give } \\
\text { the go-ahead if he or } \\
\text { she considers that the } \\
\text { project is sufficiently } \\
\text { strategic, will allocate } \\
\text { the budget and } \\
\text { resources (not IT) if } \\
\text { necessary and } \\
\text { designate the PM (S03). } \\
\text { The Promoter may } \\
\text { reject the project } \\
\text { because it is not } \\
\text { sufficiently strategic, or } \\
\text { resources are } \\
\text { insufficient (FSB). }\end{array}$ \\
\hline & S03 & $\begin{array}{l}\text { Pending } \\
\text { ranking } \\
\text { proposal by CIO }\end{array}$ & $\mathrm{CIO}$ & $\begin{array}{l}\text { The CIO will propose a } \\
\text { plan for all validated } \\
\text { projects according to } \\
\text { the PPO evaluation and } \\
\text { alignment with each } \\
\text { project strategy } \\
\text { proposed to the GB } \\
\text { (S04). }\end{array}$ \\
\hline & S04 & $\begin{array}{l}\text { Pending } \\
\text { ranking by GB }\end{array}$ & GB & $\begin{array}{l}\text { The GB will provide a } \\
\text { planning for all projects } \\
\text { prioritised according to } \\
\text { their strategic interest } \\
\text { and existing resources. } \\
\text { As a result, each project } \\
\text { may be ranked into } \\
\text { three different } \\
\text { categories: Accepted } \\
\text { (S05), Accepted, } \\
\text { Pending Resources } \\
\text { (S06), Rejected because } \\
\text { it is not strategic } \\
\text { enough for existing } \\
\text { resources (FSB). }\end{array}$ \\
\hline \multirow[t]{3}{*}{$\begin{array}{c}\text { Planning } \\
\text { Phase }\end{array}$} & S05 & $\begin{array}{l}\text { Ranked and } \\
\text { Accepted }\end{array}$ & PPO & $\begin{array}{l}\text { Together with the ITS, } \\
\text { draws up each project's } \\
\text { execution timetable } \\
\text { according to its } \\
\text { priority, existing } \\
\text { resources and the } \\
\text { services and units } \\
\text { involved. } \\
\text { Coordinates the ITS } \\
\text { together with other } \\
\text { services and units } \\
\text { necessary for the } \\
\text { project's } \\
\text { implementation. } \\
\text { Will inform the PMs so } \\
\text { they take charge of the } \\
\text { implementation (S08). }\end{array}$ \\
\hline & S06 & $\begin{array}{l}\text { Ranked and } \\
\text { Pending } \\
\text { Availability }\end{array}$ & PPO & $\begin{array}{l}\text { Will re-prioritise the } \\
\text { project if resources } \\
\text { become available } \\
\text { (S05). }\end{array}$ \\
\hline & & & & (continued on next page) \\
\hline
\end{tabular}


Table 3 (continued)

\begin{tabular}{|c|c|c|c|c|}
\hline Phase & Cod. & Name & Man. & Description \\
\hline \multirow{5}{*}{$\begin{array}{l}\text { Execution } \\
\text { Phase }\end{array}$} & S07 & $\begin{array}{l}\text { Ranked } \\
\text { unscheduled }\end{array}$ & PPO & $\begin{array}{l}\text { After trying to readjust } \\
\text { the project, it is finally } \\
\text { not strategic, and the } \\
\text { GB can decide to } \\
\text { suspend it definitively } \\
\text { (FSC). } \\
\text { Will re-prioritise the } \\
\text { project if resources } \\
\text { become available } \\
\text { (S05). } \\
\text { After trying to readjust } \\
\text { the project, it is finally } \\
\text { not strategic, and the } \\
\text { GB can decide to } \\
\text { suspend it definitively } \\
\text { (FSC). }\end{array}$ \\
\hline & S08 & $\begin{array}{l}\text { Under } \\
\text { development by } \\
\text { the ITS }\end{array}$ & ITS & $\begin{array}{l}\text { The ITS will allocate } \\
\text { the necessary resources } \\
\text { to develop the project } \\
\text { according to the } \\
\text { established timetable } \\
\text { and liaise (through the } \\
\text { PM and the PPO) with } \\
\text { the required units and } \\
\text { services. } \\
\text { The ITS may } \\
\text { temporarily suspend a } \\
\text { project in accordance } \\
\text { with the PPO due to a } \\
\text { lack of resources due to } \\
\text { some unforeseen event } \\
\text { (re-prioritisation of } \\
\text { other projects, changes } \\
\text { in budgets or allocated } \\
\text { resources, etc.) (S09). } \\
\text { The CIO may } \\
\text { temporarily suspend a } \\
\text { project in accordance } \\
\text { with the Promoter, if } \\
\text { the project's strategic } \\
\text { conditions (S10) } \\
\text { change. } \\
\text { The PM may } \\
\text { temporarily suspend a } \\
\text { project in accordance } \\
\text { with the Promoter, if } \\
\text { the operating } \\
\text { conditions (S11) } \\
\text { change. }\end{array}$ \\
\hline & S08 & $\begin{array}{l}\text { Under } \\
\text { development by } \\
\text { ITS (next call) }\end{array}$ & ITS & $\begin{array}{l}\text { If the CP deadline ends } \\
\text { and does not give time } \\
\text { to complete the project, } \\
\text { the project will } \\
\text { automatically move to } \\
\text { the same S08 state of } \\
\text { the next CP call. }\end{array}$ \\
\hline & S09 & $\begin{array}{l}\text { Suspended by } \\
\text { ITS }\end{array}$ & ITS & $\begin{array}{l}\text { The ITS may reactivate } \\
\text { a suspended project } \\
\text { according to the PPO } \\
\text { when resources are } \\
\text { available again, after } \\
\text { re-planning (S08). } \\
\text { After trying to readjust } \\
\text { the project, it is finally } \\
\text { not strategic, and the } \\
\text { GB can decide to } \\
\text { suspend it definitively } \\
\text { (FSC). }\end{array}$ \\
\hline & S10 & $\begin{array}{l}\text { Suspended by } \\
\text { CIO }\end{array}$ & $\mathrm{CIO}$ & $\begin{array}{l}\text { The CIO may propose to } \\
\text { resume a previously } \\
\text { suspended project } \\
\text { (S09). } \\
\text { After trying to readjust } \\
\text { the project, it is finally } \\
\text { not strategic, and the } \\
\text { GB can decide to }\end{array}$ \\
\hline
\end{tabular}

Table 3 (continued)

\begin{tabular}{|c|c|c|c|c|}
\hline Phase & Cod. & Name & Man. & Description \\
\hline & & & & $\begin{array}{l}\text { suspend it definitively } \\
\text { (FSC). }\end{array}$ \\
\hline & S11 & $\begin{array}{l}\text { Suspended by } \\
\text { PM }\end{array}$ & PM & $\begin{array}{l}\text { The PM may propose to } \\
\text { resume a previously } \\
\text { suspended project } \\
\text { (S09). }\end{array}$ \\
\hline & & & & $\begin{array}{l}\text { After trying to readjust } \\
\text { the project, it is finally } \\
\text { not strategic, and the } \\
\text { GB can decide to } \\
\text { suspend it definitively } \\
\text { (FSC). }\end{array}$ \\
\hline \multirow[t]{12}{*}{$\begin{array}{l}\text { Completion } \\
\text { Phase }\end{array}$} & FSA & Completed & PPO & $\begin{array}{l}\text { The project has fulfilled } \\
\text { the objectives indicated } \\
\text { in the report. }\end{array}$ \\
\hline & FSB & Rejected & & $\begin{array}{l}\text { The project is not } \\
\text { accepted in the } \\
\text { planning phase and will } \\
\text { not be included in the } \\
\mathrm{CP} \text {. There are three } \\
\text { different cases of } \\
\text { rejection: }\end{array}$ \\
\hline & & By the GB & GB & $\begin{array}{l}\text { Project rejected by the } \\
\text { GB based on the } \\
\text { prioritisation defined } \\
\text { according to the } \\
\text { university strategy and } \\
\text { existing resources. }\end{array}$ \\
\hline & & $\begin{array}{l}\text { By the } \\
\text { Promoter }\end{array}$ & Promoter & $\begin{array}{l}\text { Project rejected by the } \\
\text { Promoter. }\end{array}$ \\
\hline & & by the PPO & PPO & $\begin{array}{l}\text { Project rejected by the } \\
\text { PPO. }\end{array}$ \\
\hline & FSC & $\begin{array}{l}\text { Permanently } \\
\text { suspended by } \\
\text { GB }\end{array}$ & PPO & $\begin{array}{l}\text { After trying to readjust } \\
\text { the project, it is finally } \\
\text { not strategic or its } \\
\text { development deadline } \\
\text { within the call period } \\
\text { for the current project } \\
\text { portfolio has expired. } \\
\text { The GB decides to } \\
\text { suspend it definitively } \\
\text { for this project portfolio } \\
\text { call and studies } \\
\text { whether and how to } \\
\text { pass on to the next } \\
\text { project portfolio call. }\end{array}$ \\
\hline & & $\begin{array}{l}\text { Coming from } \\
\text { s05, S 6, S07 }\end{array}$ & & $\begin{array}{l}\text { Must be requested } \\
\text { again from scratch in } \\
\text { the new project } \\
\text { portfolio call (will be } \\
\text { duplicated to facilitate } \\
\text { a direct passage to the } \\
\text { request phase of the } \\
\text { next PP call). }\end{array}$ \\
\hline & & Coming from & & Passes directly to state \\
\hline & & S09 & & $\begin{array}{l}\text { S09 of the next call } \\
\text { (similarly to state S08). }\end{array}$ \\
\hline & & $\begin{array}{l}\text { Coming from } \\
\text { S10 }\end{array}$ & & $\begin{array}{l}\text { According to an } \\
\text { interview with the } \\
\text { Promoter, passes to } \\
\text { state } \mathrm{S} 10 \text { of the new } \\
\text { project portfolio call or } \\
\text { must be presented } \\
\text { again from scratch if } \\
\text { the wish is to continue. }\end{array}$ \\
\hline & & $\begin{array}{l}\text { Coming from } \\
\text { S11 }\end{array}$ & & $\begin{array}{l}\text { According to an } \\
\text { interview with the }\end{array}$ \\
\hline & & & & $\begin{array}{l}\text { Director, passes to } \\
\text { states } \mathrm{S} 11 \text { of the new } \\
\text { project portfolio call is } \\
\text { or must be presented } \\
\text { again from scratch if } \\
\text { the wish is to continue. }\end{array}$ \\
\hline
\end{tabular}




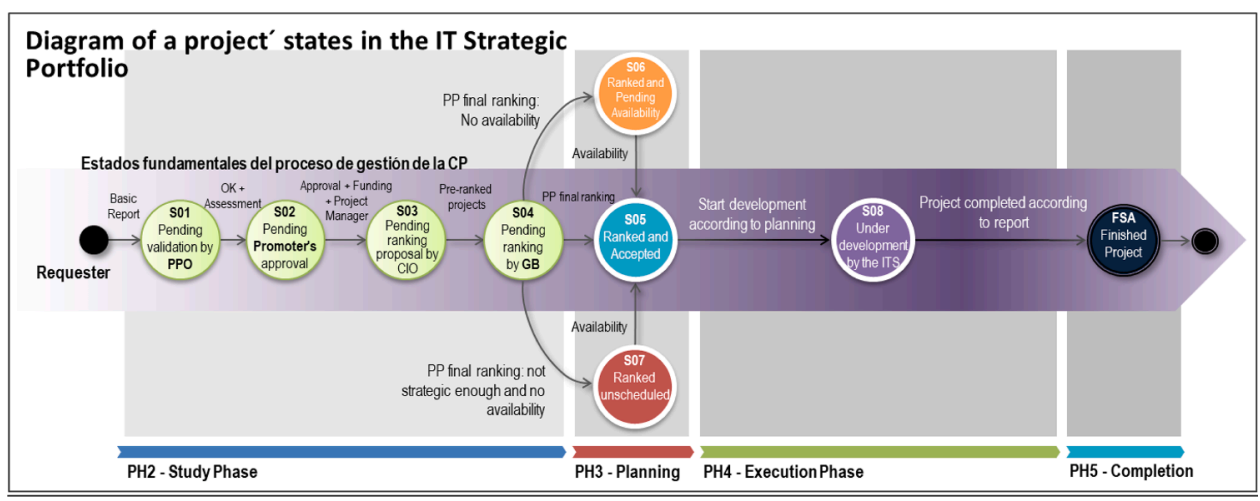

Fig. 6. A states diagram in which each IT project included in the strategic IT project portfolio can be found.

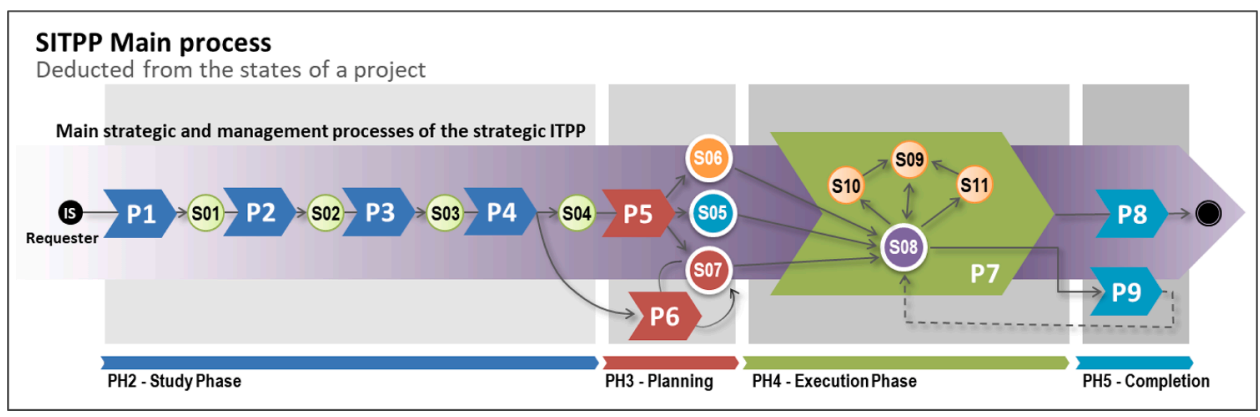

Fig. 7. Processes that make up the portfolio of strategic IT processes inferred from the possible states of an IT project in a strategic IT project portfolio.

that of accountability. The P8 process is the natural completion of processes that have developed in their entirety. The P9 process will allow current projects (state S08), that are not affected by any incident preventing them from progressing and are sufficiently near completion to automatically continue in the next portfolio call moving on to the execution state $(\mathrm{S} 08)$ of the new call.

Additionally, although as explained above the portfolio's implementation goes beyond the scope of this work for lack of space, given its relevance and to be thorough, a portfolio preparation process was incorporated (process $\mathrm{P} 0$ ). This latter process provides the decrees, regulations, criteria, schedules, documents, and forms that rule the rest of the processes.

We are now ready to specify the generic solution (Fig. 3) that we proposed in the introduction to this section. This solution proposal is

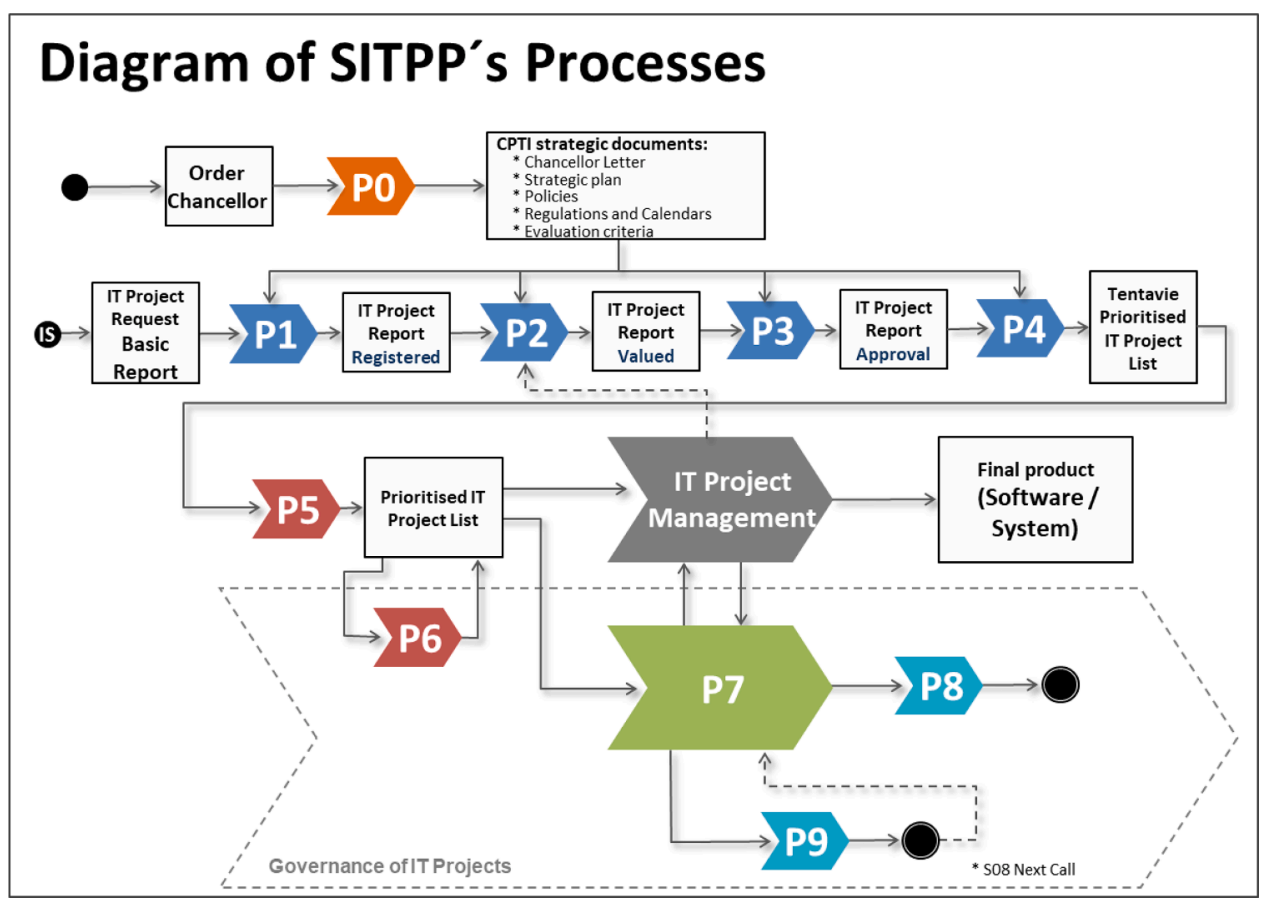

Fig. 8. Process diagram of the strategic IT project portfolio for the government, governance, and management of IT projects. 
summarised in the process diagram shown in Fig. 8.

A complete process form was drawn up for each of the ten identified processes (see Table 4). Each form details the following: its name; its inputs/outputs; the requester; the highest authority, the person in charge and the agent. It also defines its mission, controls and resources; each process is related to the phases and states affected by it. The process mission is explained and finally briefly described. These process forms could not be incorporated into this work for lack of space, but they can be consulted online [31].

As summarised in Table 4, the processes may be of a different nature. According to the above, the P0 process is related to the portfolio's implementation. This process is beyond the scope of this article, but it is very important to contemplate it within the entire process structure to understand how it influences the rest through the many necessary resources and controls it provides to launch them. Processes P1 to P5, along with P8, are mainly related to the Strategic Alignment Process, elevating decision making to the organisation's top management. Processes P6, P7 and P9 focus on regulating the Governance of IT Projects or, in other words, on managing senior management intervention throughout the development of IT Projects. The P7 process is key to this and is more complex than might appear at first glance. It is thus described in the next section (section 5) in greater detail.

\section{Governance of IT Projects}

Fig. 9 shows a diagram focused on the processes linked to Governance and its relationship with the management processes of IT Projects and Strategic Alignment. In this diagram you can see that governance weighs the most in process $\mathrm{P} 7$. This process is complex and provides the keys to establish the communication flows and protocols between all stakeholders, mainly between senior management and the different project managers.

The first process directly related to Project Governance is the P6 process. Its mission is to keep the prioritisation of SITPP dynamically updated with respect to changes. Although this process should be executed on an exceptional basis, it is important to contemplate because of the inevitable changes of all sorts that occur during a project's execution: changes in external regulations that condition the university or even create obligations for the university; changes in internal regulations affecting both current projects and projects on standby; changes in university strategy (change of Management Team, changes to the
Strategic Plan, etc.); and changes in the resources available (financial, human, technical, etc.).

Because the P7 process, i.e. IT Project Governance is the most complex, we will approach it by analysing its main subprocesses. According to this, the P7.1 subprocess monitors the project's normal state of execution (S08) making sure for example that the reports are updated, the resources are sufficient, the regulations or the strategic objectives do not change, that all the actors involved are properly informed, and that no significant incidents will potentially stop or delay the project's execution. The person responsible for this subprocess is the PPO.

If any change or incident in the university strategy affecting a project is detected, we would go to subprocess P7.2 in which the CIO, in agreement with the Project Promoter, will request that it be temporarily suspended, going from state $\mathrm{S} 08$ to state $\mathrm{S} 10$. The CIO is responsible for this subprocess.

Furthermore, if any change or incident of an operational nature is detected (for example, when changes occur in the availability of the groups, units, offices, etc. involved in a project) during the P7.1 subprocess, we pass on to subprocess P7.3 in which the Project Manager, in agreement with the Promoter and through the PPO, temporarily suspends it (S11). The person responsible for this subprocess is its project manager.

Likewise, if during the P7.1 subprocess, the ITS itself detects any technical incident (for example, a loss of personnel without the possibility of replacement, delay in the delivery of equipment or software) that affects project execution, it is possible (applying subprocess P7.4) to temporarily stop it (S09) and inform the PPO.

The CIO, through subprocess P7.5, is responsible for monitoring all the projects suspended in state S10. So, if the incidents that caused its suspension are resolved, the project would be passed on to state S09, waiting also to obtain the technical resources necessary for returning to the execution state $\mathrm{S} 08$.

Furthermore, the Project Manager is responsible, through subprocess P7.6, for monitoring all those projects suspended in state S11, so that if the incidents that caused their suspension are resolved, the project would pass on to state S09, waiting also to obtain the necessary technical resources to be able to return to the $\mathrm{S} 08$ execution state.

Finally, the ITS will monitor, through the P7.4 process, all the projects in state $\$ 09$ so that when the necessary resources are available, it will go back to the execution state (S08).

In all cases, the affected promoters must be informed of the state

Table 4

Main processes identified.

\begin{tabular}{|c|c|c|c|c|c|c|}
\hline Id & Name & Type & Phase & Initial State & $\begin{array}{l}\text { End of } \\
\text { State }\end{array}$ & Mission/Goal \\
\hline $\mathrm{PO}$ & Launch of the SITPP call & Implementation & PH1 & - & - & Launch of the next Strategic IT project portfolio call. \\
\hline P1 & $\begin{array}{l}\text { Basic Report presentation of } \\
\text { the Project }\end{array}$ & Alignment & PH2 & IS & S1 & Basic identification and formalising of a strategic IT project. \\
\hline P2 & $\begin{array}{l}\text { Preliminary Evaluation of a } \\
\text { Project }\end{array}$ & Alignment & PH2 & S01 & S02, FSB & $\begin{array}{l}\text { Assessment of the feasibility / clarity / information provided / justification / } \\
\text { minimum strategic level / ... of the project and of the report. }\end{array}$ \\
\hline P3 & $\begin{array}{l}\text { Allocation of the Project's } \\
\text { Basic Resources }\end{array}$ & Alignment & PH2 & S02 & S03, FSB & $\begin{array}{l}\text { Assigning of the Project Manager, the project Financing to the IT project } \\
\text { (quantity and origin) and the promoter's strategic evaluation. }\end{array}$ \\
\hline P4 & $\begin{array}{l}\text { Initial Project Portfolio } \\
\text { Prioritisation Proposal }\end{array}$ & Alignment & PH2 & S03 & S04 & Preliminary ranking proposal of the submitted projects. \\
\hline P5 & $\begin{array}{l}\text { Prioritisation of the IT Projects } \\
\text { Strategic Portfolio }\end{array}$ & Alignment & PH3 & S04 & $\begin{array}{l}\text { S05, S06, } \\
\text { S07 and } \\
\text { FSB }\end{array}$ & $\begin{array}{l}\text { Publishing of the results of the project portfolio call, triggering the start of its } \\
\text { execution (Phase 4). }\end{array}$ \\
\hline P6 & $\begin{array}{l}\text { Dynamic management of } \\
\text { strategic changes in the IT } \\
\text { project prioritisation }\end{array}$ & Governance & PH4 & S05, S06, S07 & $\begin{array}{l}\text { S05, S06, } \\
\text { S07 }\end{array}$ & Keep SITPP's prioritisation dynamically up-to-date in the face of change. \\
\hline P7 & $\begin{array}{l}\text { Project Development } \\
\text { Governance }\end{array}$ & Governance & PH4 & S05 & $\begin{array}{l}\text { S08 (S09- } \\
\text { S10-S11) }\end{array}$ & Monitoring of Project Development Governance. \\
\hline P8 & $\begin{array}{l}\text { Closing the Current Project } \\
\text { Portfolio Call }\end{array}$ & Alignment & PH5 & $\begin{array}{l}\text { S08, S05, S06, } \\
\text { S07, S09, S10, } \\
\text { S11 }\end{array}$ & $\begin{array}{l}\text { FSC or } \\
\text { FSA }\end{array}$ & $\begin{array}{l}\text { Finalize the development activity of SITPP projects and prepare a series of } \\
\text { final reports including achievements, incidents and proposals... aimed at: } \\
\text { - The GB for Strategic Decision-Making } \\
\text { - TheUniversity Community for accountability }\end{array}$ \\
\hline P9 & $\begin{array}{l}\text { Extension of the project's } \\
\text { execution to the next call }\end{array}$ & Governance & PH5 & S08 & $\begin{array}{l}\text { S08 (S08 } \\
\text { next call) }\end{array}$ & $\begin{array}{l}\text { Ensure the continuity of a current project that requires a relatively short } \\
\text { completion time. }\end{array}$ \\
\hline
\end{tabular}




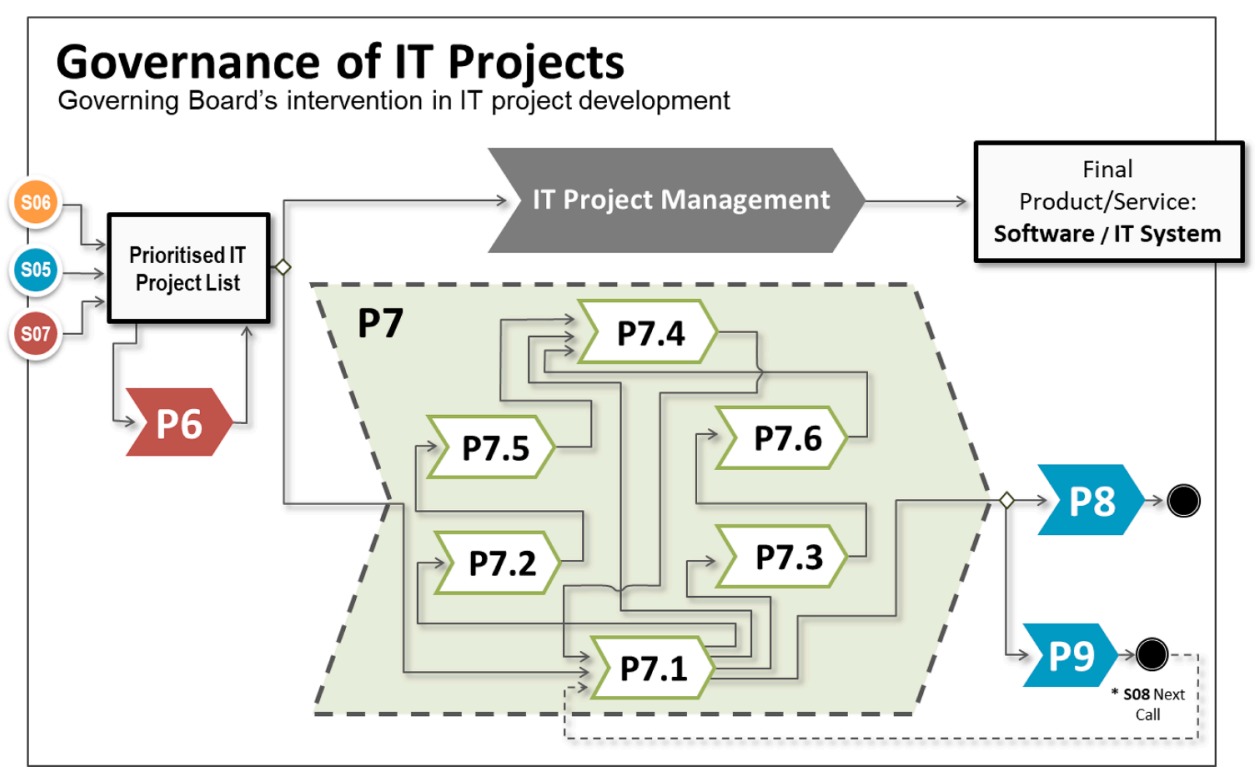

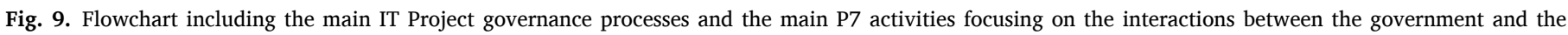
management of IT projects via IT project governance.

changes.

The P7.1 and P7.4 process tandem is the meeting point between the Strategic Projects' execution Governance and their Technical Management.

The P7.4 process is tasked with ensuring the ITS's maximum autonomy in developing a project's execution by applying methodologies, standards and frameworks to develop IT software, services and systems-such as ISO / IEC 38500, ISO / IEC 20000, COBIT or ITIL-in each case.

Finally, P9, called Extension of a project's execution to the next call, is responsible for ensuring the continuity of a current project requiring a relatively short completion time. The $\mathrm{P} 8$ process is the natural process of finalising fully developed processes. For its part, the P9 process will allow projects that are currently running (state S08), are unaffected by any incident that would prevent them from moving forward, and that foreseeably have a sufficiently close end date, to be automatically extended to the next portfolio call, moving on to the new call's execution state $\mathrm{S} 08$ (identified as S08*).

\section{Case Studies and Validation}

The IT Strategic Project Portfolio we put forward in our study is defined and conceived as a governance tool. The fact that it is a governance tool, however, does not guarantee that it is an effective Good Governance tool. The objective of this section is therefore to demonstrate that it is, and this constitutes the main hypothesis of our work.

We based this demonstration on two studies. The first is an analysis of nine use cases-specifically nine public universities that are implementing or have implemented this model—via a series of interviews with executives. The second is the in-depth analysis of the historical data of one of these cases, that of the University of Alicante. Indeed, these latter data are at our disposal and the authors of the present work actively participated in all the phases of that project. The first study, despite being mostly qualitative, is relevant because of the breadth of the vision it offers, originating in the perceptions of the senior managers involved in the implementation. The second study is a specific case, though it is also more quantitative in nature. It includes accurate historical data allowing for regressions and projections that help to understand how the proposal emerged, where it is heading and the impact it has had, according to the directors and managers, on the progress made towards Good Governance.

\subsection{General study}

Although the number has now grown, almost doubled in fact, we needed in the present study for the proposals to be sufficiently substantive to obtain truly significant conclusions.

The study consisted of a double interview with each organisation's main actors at different levels of responsibility, from chancellors to directors of computer services. The double interview consisted of the same written form addressed to all organisations and actors and a second individualised personal interview. Both the full interviews and the detailed conclusions can be found in [11]. The members of our research group, within their role of researchers, contributed to creating the surveys; one member, within the role of IT Vice-Manager of a participating institution contributed to the implementation; and as a promoter and co-author of the book, participated in the publication of the results [11]. This latter publication was mainly for dissemination purposes and the interviews were merely designed to demonstrate the positive outcomes of the proposed strategic approach to the top management of other organisations. Moreover, the information is mainly qualitative in nature. Despite the above, given the interviewees' high degree of qualification, the extent of their implication, their diversity, and the striking coherence of their answers - hardly any outliers were found-we believe that these interviews constituted a rich source of information that is useful to determine whether the prioritisation and governance of strategic IT projects helps to improve institutions' IT Governance and Good Governance.

The methodology followed to draw the conclusions was as follows: (a) all the answers in the interviews relating to changes in managers' visions were identified, the information was standardised and synthesised in a table (Table 5) that correlates these views before and after applying the model; (b) the expressed advantages and disadvantages were also retrieved from interview answers, and; (c) a table was finally drawn up identifying the accomplishments regarding IT Governance and Good Governance principles based on the previous analyses,

Table 5 accordingly summarises the managers' generalised change of vision regarding the significance of governing IT. As can be observed, there is a clear trend towards involving all the actors in the governing of their universities.

Below we summarise the main advantages of the model, as extracted from the analysis of the questionnaires and interviews: 
Table 5

Summary of the progressive changes in mentality detected in the organisations after implementing the strategic portfolio model: prioritisation of projects and governance regarding execution, development and evaluation.

Before the setup
The IT Service is in charge of identifying
and deciding which IT projects are
developed
No complete annual planning exists a
the one that does exist is not made
public.
There is no information about what
kinds of IT projects are implemented
Only the IT Service is aware of each
project's execution status.

There is no project portfolio or, if it does exist, only IT knows about it.

The university community generally is totally unaware of what projects are being executed, according to which criteria, etc. despite being the main recipient of the services and applications.

Among the top management, only the IT Vice-Manager is directly involved in IT projects.

An IT project is understood to be any project that broadly involves technologies and units. The departments or users to which they are directed are considered as secondary.

No defined budget is agreed upon by the whole government team for the development of IT projects.

The strategic impact of the executed projects is not known.

Members of the management team believe that only the IT Vice-Manager should know and make decisions about projects

Management team members propose projects that largely involve technology without taking their budget, impact and strategic indicators into account. They do so, guided only by the particular interests of their domain of management.

Management team members do not feel implicated in other projects that come from other domains and believe that each manager should focus solely on their own field of action.
After the setup

The board decides which projects are to be developed each year.

A planning exists and it is made public.

The following is known:

- the amount of projects put forward or rejected

- how they are aligned with strategic objectives

- their execution status at any time in a project are informed of each project's implementation status.

A strategic project portfolio exists and the information is available to the entire community at all times.

The university community can know at any time which projects have been or are process by presenting their own projects.

The entire Board of Directors is involved in IT projects, understanding that they are transversal in the organisation. An IT project is transversal in the entire organisation.

A global budget is established for all IT actions. This budget is agreed upon by the entire government team.

Indicators are proposed and each project's true impact is evaluated after being launched.

All members of the governance team are involved in making decisions about any strategic IT project.

The members of the governance team propose IT projects that follow a strategic line, aware that they have to compete for all types of resources with the rest of the projects proposed in other domains: time, investment, strategy, opportunity, etc.

The members of the management team understand the strategic importance of projects and that they affect the organisation's overall strategy. They are widely involved in decision-making. Top management and each unit involved being executed and can take part in the

- In all the cases analysed, the portfolio's implementation was considered to have helped them to noticeably evolve both in their project management maturity model and in the Good Governance maturity model: the necessary governance and management structures were identified, created and, most importantly, consolidated; the senior management's involvement (principle of responsibility) was achieved in IT project decision-making (we must remember that IT projects are strategic for the organisation).

- In most of the cases studied, a series of viable and sustainable processes were implemented over time ensuring the continuity of the portfolio across changes in the government and management bodies and structures.

- The objective of implementing the proposed portfolio model is to advance IT Governance and Good Governance generally. Therefore, it is also essential to verify in the implemented case study that in practically all cases and for all the profiles interviewed, considerable progress was believed to have been made in aligning IT projects with business objectives and that the model was key in this evolution: both to achieve it and to give it continuity over time.

- The ratio between the projects requested each year by different unit managers and the projects that the organisation was able to execute was normalised.

- It was possible to better understand and adjust the budgets and resources dedicated to IT projects.

- Greater transparency was achieved in decision-making processes, which, in turn, improved the communication between the organisation's different levels and structures. This was observable through the senior management's greater understanding and disposition to abide by the decisions and strategic dispositions adopted regarding IT projects.

- Senior management gradually understood the importance of strategic IT projects and the key role of their involvement in decisionmaking.

A highly relevant fact obtained from the interviews is that in practically all cases, it was the CIO's convincing and leadership that was key to the success of the implementation, acting as a cohesive link between Governance and Management; an additional factor was involving the General Director, the Chancellor (or the CEO in general) and the government team in the project from the very beginning, i.e. immediately relocating the Governance leadership.

Notwithstanding the above, there were also some negative aspects that must be addressed in the future as well as certain recurring risks, though they were not generalised. These aspects listed below:

- It is essential and very difficult to convince top management that strategic IT project decisions be taken by the most senior government levels.

- Resistance in the IT service due to the apparent loss of decisionmaking power.

- The implementation of the portfolio is costly in effort and time: agreeing on the criteria, defining the processes, evaluating the strategic weight of each aspect of the projects, adequately training the personnel and, above all, achieving cultural change in the organisation.

In short, the experience was deemed satisfactory in all cases (even in cases in which it was not consolidated) and led to substantial growth in the maturity model of both the project management and the organisation's Good Governance.

Finally, the universities' main achievements owing to the model's implementation are correlated with IT Governance and Good Governance principles (see Table 6). Once again, a clear improvement in the systems of government can be observed, despite the data naturally being of a qualitative nature.

Historical analysis of calls for strategic IT projects

In this section, we perform a detailed analysis of the results obtained in one case: that of the University of Alicante. Our research group participated and was directly responsible, not only for creating the model, but also implementing and monitoring at this university. A tangible result of this work is the creation of an application to manage the strategic project portfolio [32] which includes, among many other functionalities, a dashboard that supports the decision-making process (Fig. 10 shows a screenshot of the application with data from the last fiscal year). This dashboard allows analysing the entire process presented in this work: from the presentation of proposals, to the evaluation of their impact after being launched, to the prioritisation and governance of development processes. Thanks to this tool, the entire 
Table 6

Analysis of the evolution of the IT Government and Good Governance maturity model based on the achievements regarding the underlying principles.

\begin{tabular}{|c|c|}
\hline Principles & $\begin{array}{l}\text { Most relevant achievements supported by the } \\
\text { model's implementation }\end{array}$ \\
\hline Responsibility & $\begin{array}{l}\text { Board members have understood that IT projects are } \\
\text { strategic, transversal in the organisation, and that it is } \\
\text { the responsibility of the entire board to know these } \\
\text { projects and actively participate in decision-making. } \\
\text { Responsibility for an action goes hand in hand with the } \\
\text { authority to execute it. }\end{array}$ \\
\hline Strategy & $\begin{array}{l}\text { Proposers understand the importance of justifying the } \\
\text { project's strategic value, senior management } \\
\text { prioritises projects based on their strategic value, } \\
\text { taking into account current IT capabilities. }\end{array}$ \\
\hline Acquisition & $\begin{array}{l}\text { The model proposes a common fund for the financing } \\
\text { of strategic IT project development. In this way, all } \\
\text { projects compete on an equal footing for this essential } \\
\text { resource through the allocation of a budget, naturally } \\
\text { linked to the organisation's strategic interests. }\end{array}$ \\
\hline Performance & $\begin{array}{l}\text { Thanks to the senior management's involvement, the } \\
\text { role of IT is naturally linked to supporting the } \\
\text { organisation and providing services to fulfil current } \\
\text { and future business objectives. All project proposals } \\
\text { should provide indicators that allow evaluating each } \\
\text { project's true impact on the overall strategy during the } \\
\text { completion phase. }\end{array}$ \\
\hline Compliance & $\begin{array}{l}\text { Strategic alignment entails the obligation to comply } \\
\text { with all laws and regulations, both internal and } \\
\text { external. }\end{array}$ \\
\hline Human factor & $\begin{array}{l}\text { The proposed model encourages IT projects to be } \\
\text { initiated by any university community: student } \\
\text { representatives, administration and services staff, } \\
\text { faculty and researchers. This ensures that current and } \\
\text { future needs of all those involved are taken into } \\
\text { account. }\end{array}$ \\
\hline Transparency & $\begin{array}{l}\text { The entire community can access the information on } \\
\text { the process in real time through the management } \\
\text { platform (see Fig. 10). Full transparency regarding } \\
\text { each project's prioritisation, implementation status } \\
\text { and evaluation results is thus ensured. }\end{array}$ \\
\hline Participation & $\begin{array}{l}\text { This transparency throughout the process encourages, } \\
\text { in turn, not only senior management and intermediate } \\
\text { managers to take part, but also the whole community. } \\
\text { They can become involved at any time in proposals of } \\
\text { strategic IT projects and be aware of decisions and } \\
\text { results. }\end{array}$ \\
\hline $\begin{array}{l}\text { Responsibility and } \\
\text { Accountability }\end{array}$ & $\begin{array}{l}\text { From the very start, each project must be accompanied } \\
\text { by a set of indicators allowing to measure its impact on } \\
\text { the community and its strategic value. This makes it } \\
\text { easier to hold senior management accountable for its } \\
\text { performance. }\end{array}$ \\
\hline Reuse of information & $\begin{array}{l}\text { The moment the reuse of information is included in the } \\
\text { good governance principles incorporated into the } \\
\text { university's strategic plans (thanks to the requirement } \\
\text { of strategic project alignment), the reuse of } \\
\text { information becomes a key factor through its } \\
\text { publication and dissemination in formats that enable } \\
\text { and promote its reuse and as a way to promote } \\
\text { entrepreneurship and create added value. }\end{array}$ \\
\hline
\end{tabular}

university community has access to detailed, quantitative and real-time information on each IT project's status and execution, both past and present. The prioritisation criteria and the result of the process are also disseminated on the IT Project Management Office's website [33]. Additionally, much of the data considered useful to the research community or for entrepreneurship are published in the form of reusable data sets in the University of Alicante's Open Data portal [34]. If they are not published, a request can be sent via the University of Alicante's Transparency Portal [35]. We will use some of this data to illustrate the model's advantages regarding improvements to IT project management and progress in particular in IT Governance, as well as Good Governance, generally.

Fig. 11 summarises the historical data series (since 2014) at the (annual) close of each call and shows the open call's current status (call
2020) [33]. The data presented is quantitative in nature and focuses on the states of each IT project (see section 4.C). The data from the last call, although seemingly less relevant, help us to illustrate how the projects behave throughout a call, in terms of achieved status. In addition, they provide a better overview and a vision of the expected trend.

The first obvious conclusion that can be drawn from the finalised calls is that it has seldom been necessary to definitively suspend a development process that has already begun (FSC: Permanently suspended). On the other hand, the share of projects that could not be carried out due to a lack of time and resources (FSC: Rejected) ranges from $20 \%$ to $30 \%$. A strikingly big number of projects could not be completed and had to be carried over to the next call (S08*: under development of ITS) in all calls. In the same way, the number of fully completed projects in each call (FSA: Completed) seems highly variable and does not reach significant percentages.

To understand this seemingly erratic behaviour, Fig. 12 shows a graph with a series of data aggregations, together with an analysis of the trends of these aggregations based on a simple linear regressive study, providing a much better illustration of the model's general evolution over time.

The main conclusion of this latter analysis is that the university has gradually improved its capacity to develop new IT projects (Presented: sum of all IT projects). This curve follows a linear trend (a 94\% determination coefficient) with a slope close to $18 \%$. The progress is all the more notable if one considers that the IT resources, whether human or material, have showed no variation throughout the historical series. However, based on the conclusions obtained from all the cases under study (Tables 5 and 6), the organisation and training of the entire chain of command has substantially improved, from senior management to the IT Service management, to the direction of the university's different functional units involved in each project (personnel, accounting, economic affairs, faculty, students, academic management, research, social affairs, international, studies, departments, faculties, institutes, etc.). Based on all these analyses, the fact of incorporating a strategic vision, appropriately articulated with the direction and management, has clearly led to managing existing resources more efficiently and to largely increasing the capacity to undertake IT projects.

A similar pattern regarding the capacity to finalise projects each year can be observed (Developed: FSA + S08*). We have already seen that the separate analysis of fully completed projects (FSA) and projects to be extended to the next call (S08*) produces apparently erratic results, in some cases considered as outliers. In reality, the extended projects $\left(\mathrm{S} 08^{*}\right)$ are those having exceeded at least $80 \%$ of their execution. In practice, some validation test or some small development is missing that should not usually take more than a few weeks, or a month at most. For this reason, aggregating these projects ( $\mathrm{S}^{*}$ ) with the completely finalised projects (FSA) gives a more accurate reflection of the reality. The result is the Developed curve (FSA + S08*). In this case, all the existing information becomes more coherent and the apparent outliers disappear (for example, in 2018). The regressive analysis of this aggregation shows a power trend, with an $\mathrm{R}^{2}$ of $85 \%$ and a projection that predicts a current call completion for over 150 completely finalised projects or of which at least over $80 \%$ are finalised.

Finally, one can also observe an exponential trend (R2 of 70\%) in the rise of project rejections (Rejects: FSB + FSC). This is the point where each organisation must decide whether to invest in more resources to execute IT projects or prefer to stabilise the curves. From the data obtained in the last 7 years, and despite the fact that the determination coefficient barely reaches $70 \%$, it is not possible yet to conclude that this asymptote has been reached. It is foreseeable, however, that if the conditions do not change, it will soon happen.

This quantitative analysis allows us to validate the model's effectiveness and its contribution to some specific aspects of IT Government and Good Governance. But it is difficult to establish a direct link. To get closer to the strategic vision, a simple survey was conducted with the university executives following each call, from the IT Vice-Manager to 


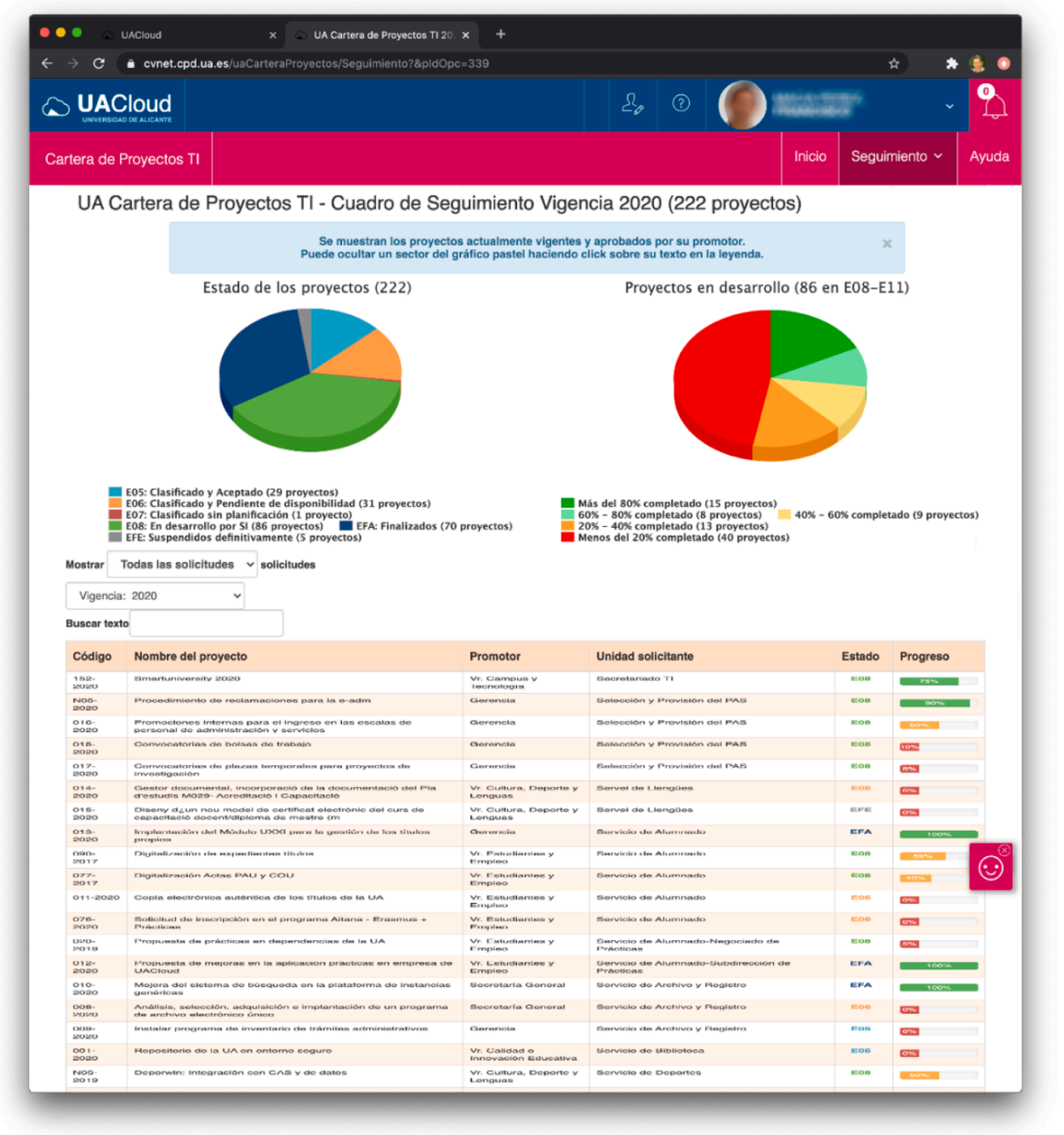

Fig. 10. Strategic Portfolio Dashboard Application available in the university's cloud [32].

the director of the IT service. They were asked their opinion about the university's status regarding the IT Governance and Good Governance principles that best defined the objectives of our study: Responsibility, Strategy, Acquisition, Performance, Compliance, Human factor, Transparency, Participation, Responsibility, Accountability and Reuse of information. Participants only had to give a score between 0 and $100(0$ : the principle is not fulfilled to any extent and 100: the principle is entirely fulfilled). The number of surveys varies each year depending on the participants in the different IT projects and ranged from 8 to 11 managers [36]. For our validation, a summary of the arithmetic average of these values was collected for each principle and call, expressing it as a percentage. Fig. 13 shows a radar graph representing this perception that was appropriately quantified to show the organisation's evolution over the years with respect to IT Governance and Good Governance principles.

The graph in Fig. 13 illustrates the notable evolution of a number of principles, such as transparency, human factor, performance and accountability. It also shows some important shortcomings regarding participation and acquisition. On the other hand, despite the principles of Responsibility and Reuse of information undergoing a substantial evolution, a clear stagnation in recent years can be observed.

We must remember that while this information is based on experience and highly representative, it is also of a subjective nature. Indeed, it is based on the quantification of qualitative information and, most significantly, no linear correspondence necessarily exists between the evolution of a given principle and the model's implementation. For example, the transparency principle evolved to a greater extent than the rest, though the University of Alicante did in fact launch its Transparency Portal initiative over the same period. Moreover, this IT project may not have been considered strategic had it not been for the prioritisation of IT projects. Improvements are also clearly visible and what we wished to know was whether the information was consistent. For this, a general maturity analysis was performed (see Fig. 14) based on a regression study of the curve representing the sum of the evolution of all the principles over time.

As shown in Fig. 14, the curve's evolution followed a logarithmic dynamic with an accommodation factor of $96 \%$, which allows us to infer that the model will continue to evolve in the coming years, although at an increasingly slower speed.

To summarise, both studies perfectly complement each other and although no formal framework is presented, they clearly illustrate that the proposed strategic portfolio model based on strategic IT project prioritisation and the definition of a clear governance protocol during the projects' development, launch and evaluation, effectively contributed to the organisation's greater maturity regarding both, IT Government and Good Government.

\section{Conclusions}

This work presented a methodology to implement and run a strategic 


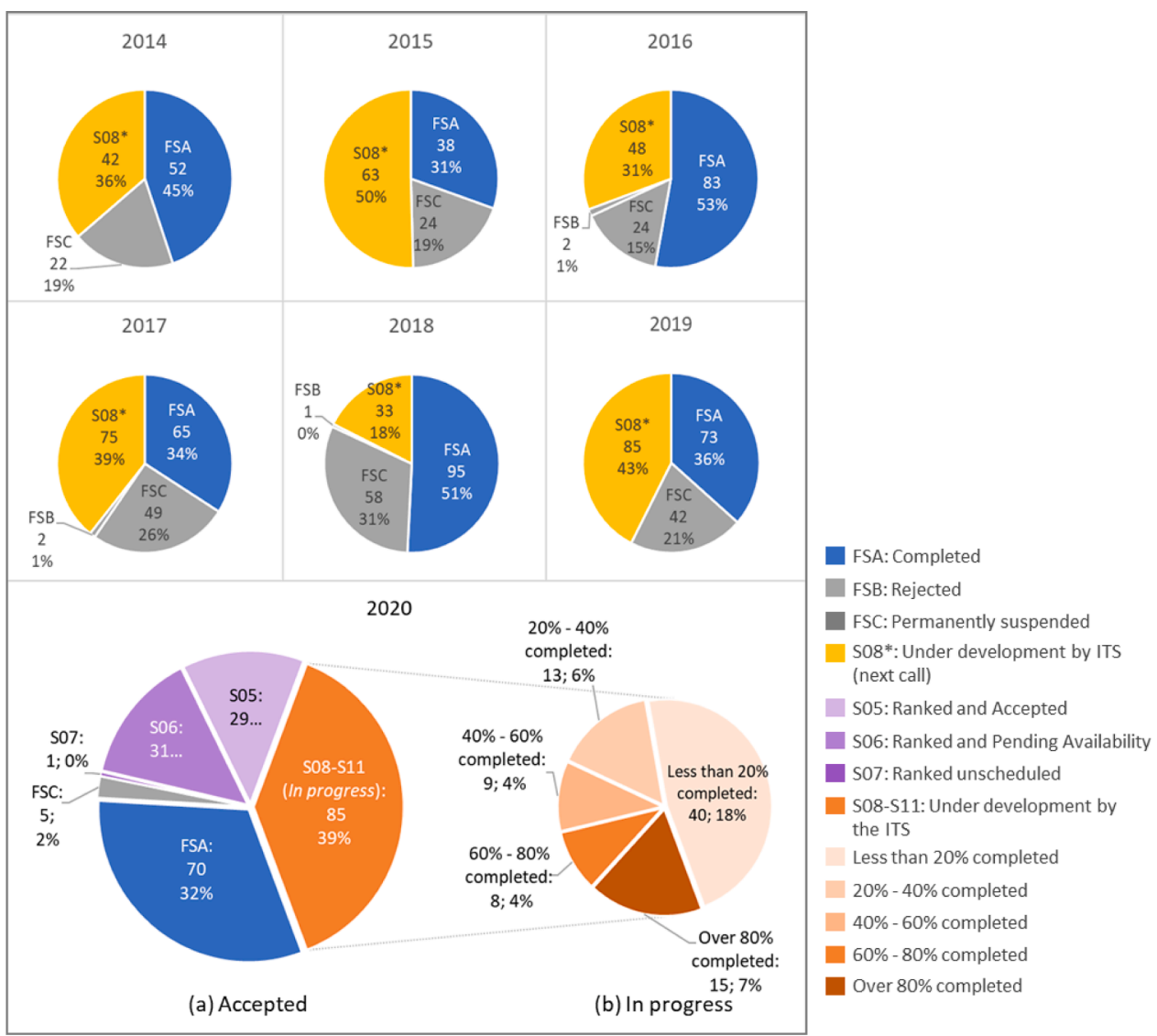

Fig. 11. Evolution of the finalisation of strategic IT project calls by year. Data source [33].

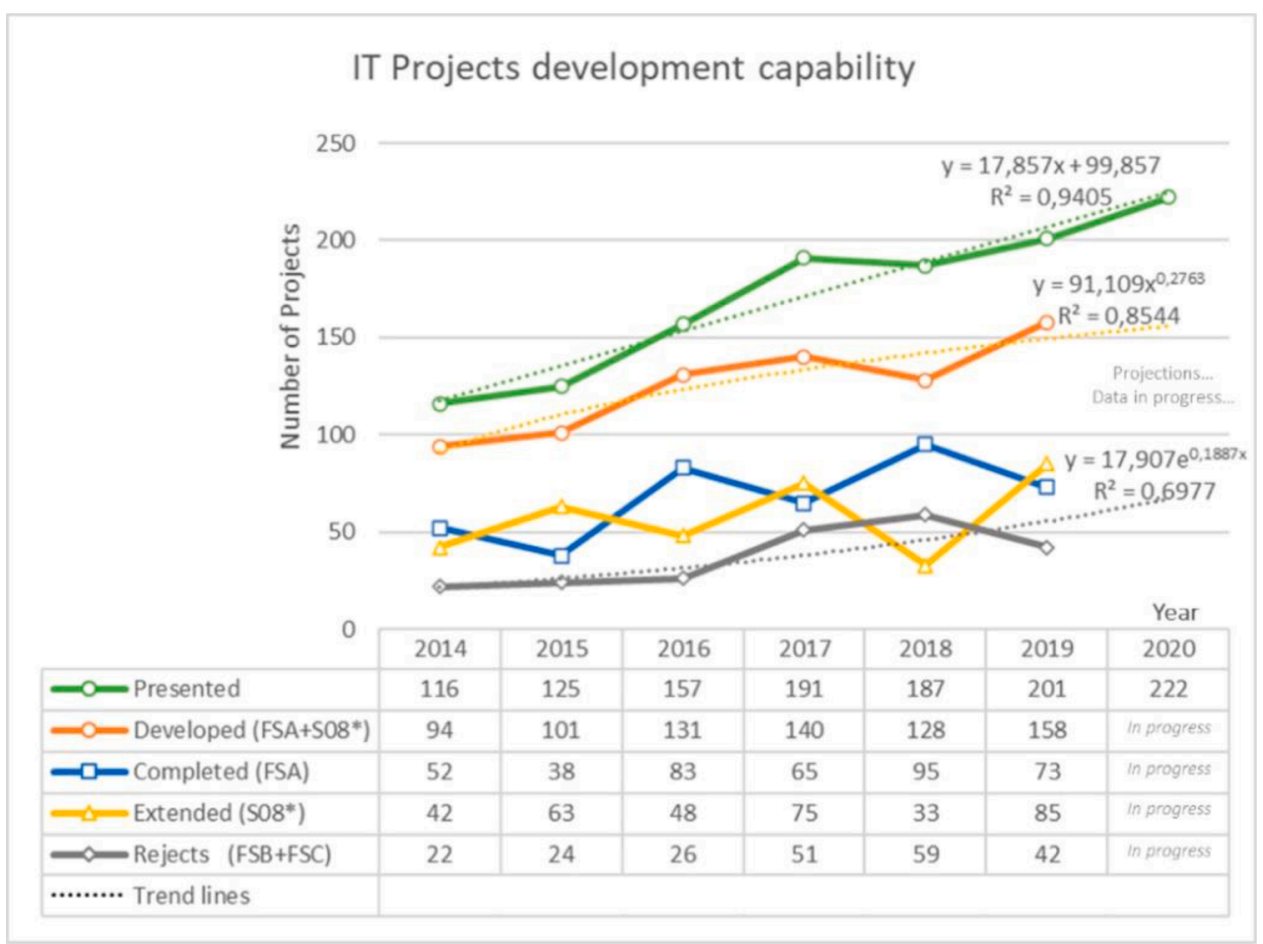

Fig. 12. Trend in the capability to manage strategic IT projects. Data source [33]. 
Evolution of the principles that lead Good Governance and IT Governance at the University of Alicante

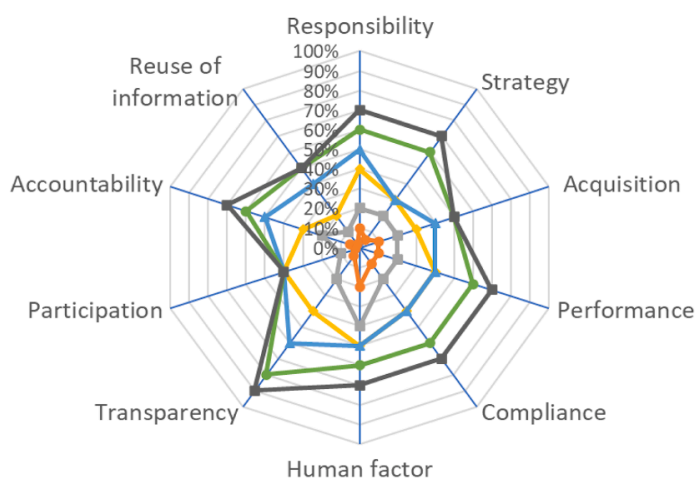

$\because 2014 \rightarrow-2015 \rightarrow 2016 \rightarrow 2017 \rightarrow 2018 \rightarrow-2019$

Fig. 13. Radar chart of the evolution of the principles ruling Good Governance and IT Governance at the University of Alicante. Source of data: [36].

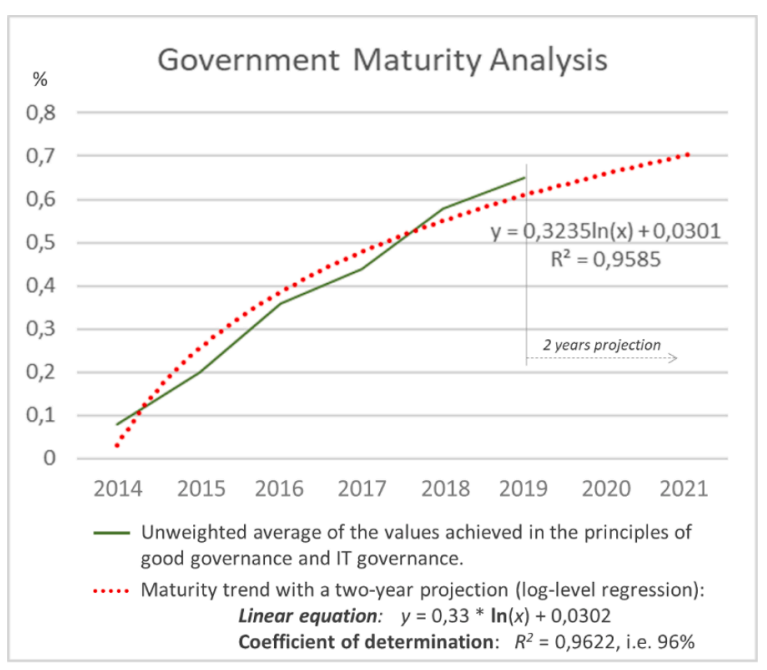

Fig. 14. Government Maturity Analysis. Source of data: [36].

portfolio of IT projects.

From a more scientific viewpoint, the proposal provides a formal model of a strategic IT project portfolio that succeeds in aligning IT projects with business objectives and strategy.

From a functional and applied perspective, this type of strategic portfolio can be a good tool to strategically manage IT projects, thanks to the fact that it elevates strategic decisions to an organisation's most senior management levels, strengthening leadership and improving communication and cooperation. Yet it also ultimately constitutes a series of good IT Governance and Good Governance practices.

The analysis of the different case studies shows that: the model is reproducible in different organisations regardless of their structures; that it is sustainable over time despite changes in the organisation; that it is compatible with the organisation's existing Governance and Management of IT projects-which is consistent with the standards of Good Governance, Governance, Management and Operation (ISO/IEC 38500, ISO/IEC 20000, COBIT, ITIL, etc.); it increases the organisation's Good Governance level of maturity; and it contributes effectively to the principles of responsibility, strategy, acquisition and performance expected of Good Governance.

Currently, the model continues to be refined based on the results of past experiences, it is being implemented in other organisations, and an experience-sharing network is today under construction.

From a scientific perspective, some problems were identified and need to be solved: a major bottleneck arises due, first to the huge amount of information necessary for the decision-making in the project prioritisation phase, and second, due to many senior managers' lack of experience in these types of projects. To solve this problem, we are currently working in the medium term on incorporating Artificial Intelligence and Data Mining techniques in the medium term. The latter will help to automate the prioritisation process and facilitate decisionmaking by senior management.

\section{Declaration of Competing Interest}

The authors declare that they have no known competing financial interests or personal relationships that could have appeared to influence the work reported in this paper.

\section{Supplementary materials}

Supplementary material associated with this article can be found, in the online version, at doi:10.1016/j.csi.2021.103514.

\section{References}

[1] I. Kawtar, D. Karim, B. Salah, Proposal model of change for Business IT Alignment, Procedia Computer Science 164 (2019) 96-104.

[2] A. Al-Surmi, G. Cao, Y. Duan, The impact of aligning business, IT, and marketing strategies on firm performance, Industrial Marketing Management 84 (2020) 39-49.

[3] G. Cserháti, L. Szabó, The relationship between success criteria and success factors in organisational event projects, International Journal of Project Management 32 (4) (2014) 613-624.

[4] M. Chi, R. Huang, J.F. George, Collaboration in demand-driven supply chain: Based on a perspective of governance and IT-business strategic alignment, International Journal of Information Management (2020), 102062.

[5] ISO/IEC (2015) 38500: Governance of Information Technology for the Organization. Geneva: ISO/IEC. http://www.iso.org/iso/catalogue_detail?csnu mber $=62816$. (last access 5/10/2020).

[6] M. Maryska, P. Doucek, L. Nedomova, Corporate Informatics and Strategic Management, Procedia Economics and Finance 26 (2015) 651-656.

[7] Z. Alreemy, V. Chang, R. Walters, G. Wills, Critical success factors (CSFs) for information technology governance (ITG), International Journal of Information Management 36 (6) (2016) 907-916.

[8] Toomey, M. (2009). Waltzing With the Elephant: A Comprehensive Guide to Directing and Controlling Information Technology. Available at: http://trove.nla.gov.au/v ersion/45114006. ISBN: 9780980683004.

[9] ISACA (2012) COBIT 5: A Business Framework for the Governance and Management of Enterprise IT. Available at: http://www.isaca.org/cobit/documents/cobit-5-int roduction.pdf. ISBN: 978-1-60420-237-3.

[10] Gómez, J. (ed.) (2017). UNIVERSITIC 2017. Análisis de las TIC en las Universidades Españolas. Crue Universidades Españolas, Madrid-España, 2017.

[11] A. Fernández-Martínez, F. Llorens-Largo, C. Juiz-García, F. Maciá-Pérez, J. M. Aparicio-García, Cómo priorizar los proyectos TI estratégicos para tu Universidad, Publicacions Institucionals de la Universitat d'Alacant, 2019.

[12] S. Kunisch, T. Keil, M. Boppel, C. Lechner, Strategic initiative portfolios: How to manage strategic challenges better than one at a time, Business Horizons 62 (4) (2019) 529-537.

[13] P.y Weill, J.W. Ross, IT Governance: How top performers manage IT decision rights for superior results, Harvard Business School Press, Boston, 2004.

[14] M. Martinsuo, J. Geraldi, Management of project portfolios: Relationships of project portfolios with their contexts, International Journal of Project Management (2020).

[15] B. Gómez, B. Bermejo, C. Juiz, IT Governance and Its Implementation Based on a Detailed Framework of IT Governance (dFogIT) in Public Enterprises. Information Technology Governance in Public Organizations, Springer, Cham, 2017, pp. 133-155.

[16] Mueller, L., Magee, M., Marounek, P., y Phillipson, A. (2008). IBM IT Governance Approach Business: Performance Through It Execution.

[17] C. Juiz, M. Toomey, To govern IT, or not to govern IT? Communications of the ACM 58 (2) (2015) 58-64.

[18] M. Gërvalla, N. Preniqi, P. Kopacek, IT infrastructure library (ITIL) framework approach to IT governance, IFAC-PapersOnLine 51 (30) (2018) 181-185.

[19] T. Sethibe, J. Campbell, C. McDonald, IT governance in public and private sector organisations: examining the differences and defining future research directions, ACIS 2007, Proceedings (2007) 118.

[20] A. Khalfan, T.G. y Gough, Comparative analysis between the public and private sectors on the IS/IT outsourcing practices in a developing country: a field study, Logistics Information Management 15 (3) (2002) 212-222. 
[21] N Al Qassimi, L Rusu, IT governance in a public organization in a developing country: a case study of a governmental organization, Procedia Computer Science 64 (2015) 450-456.

[22] J. Gomes, N. de Macedo, L.Y. Kussam, R.M. Nogueira, C.H. Arima, Gestão de riscos de segurança da informação e governança de TI no setor público, $X$ Workhop de pós-graduaçao e Pesquisa do Centro Paula Souza: ENGEMA. São Paulo 7 (October 2015) (2016) 753-763.

[23] E. Orta, M. Ruiz, Met4ITIL: A process management and simulation-based method for implementing ITIL, Computer Standards \& Interfaces 61 (2019) 1-19.

[24] Y. Bounagui, A. Mezrioui, H. Hafiddi, Toward a unified framework for Cloud Computing governance: An approach for evaluating and integrating IT management and governance models, Computer Standards \& Interfaces 62 (2019) 98-118.

[25] Maciá Pérez Francisco, Iren Lorenzo Fonseca, Berná Martínez, José Vicente, A formal framework for modelling complex network management systems, Journal of Computers 40 (2014) 255-269.

[26] F. Maciá-Pérez, I. Lorenzo-Fonseca, J.V. Berná-Martínez, J.M. Sánchez-Bernabéu, Conceptual Modelling of Complex Network Management Systems, Journal of Computers 10 (5) (2015) 309-320.

[27] H.E. Eriksson, M. Penker, Business Modeling with UML: Business Patterns at Work, John Wiley \& Sons, Inc., New York, 2000.
[28] M. Weske, Business Process Management: Concepts, Languages Architectures, Springer, 2019, 3662594323. ISBN.

[29] AXELOS (2019). ITIL Foundation, ITIL 4 Edition. TSO TSO (The Stationery Office). ISBN: 9780113316076.

[30] ISO/IEC (2015) 2000: ITIL Information Managemente. IT Service Management.A practical guide. Avaliable at: https://www.iso.org/publication/PUB100441.html.

[31] F. Maciá Pérez, I. Lorenzo Fonseca, J. Berná Martinez, IT Strategic Project Portfolio - Process Sheets, 2020.

[32] UACloud. Portfolio Projects. Aplicación para la gestión de la Cartera Estratégica de Proyectos TI. https://si.ua.es/en/manuales/uacloud/uacarteraproyectos/port folio-of-projects.html. (last access 05/10/2020).

[33] Oficina de Gestión de Proyectos TI, Vicerrectorado de Campus y Tecnología de la Universidad de Alicante, Portal Web, https://web.ua.es/es/vr-campus/convoca torias/cartera-de-proyectos/cartera-de-proyectos-ti-estrategica.html. (last access el 05/10/2020).

[34] Portal de Datos abiertos de la Universidad de Alicante, Portal Web, https://datos. ua.es/ (last access 05/10/2020).

[35] Portal de Transparencia de la Universidad de Alicante, Portal Web, https://t ransparencia.ua.es/ (last access 05/10/2020).

[36] Maciá Pérez, F., Berná Martinez, J., Lorenzo Fonseca, I., (2020). Dataset: IT governance maturity and good governance surveys. http://hdl.handle.net/100 $45 / 109540$. 